\title{
Three Dimensional Product Presentation Quality Antecedents and Their Consequences for Online Retailers: The moderating Role of Virtual Product Experience
}

\begin{abstract}
This study investigates the impact of three dimensional (3D) product presentation quality (3D-Q) on attitude toward presented product and attitude toward website which in turn impact users'satisfaction. Therefore, this research developed a hypothetical online retailer website, which presents a variety of 3D laptops that allowsusers to control the content and form of the 3D flashes. We measured 3D-quality based on a multi-dimensional construct. In other words, we define and operationalize 3D-quality based on information quality, system quality, authenticity, and enjoyment (second-order). We employed a nonstudent sample $(n=410)$ to collect the data. We find that 3D-quality determines perceptions of attitude toward presented product and attitude toward website, which in turn influence users' satisfaction. Furthermore, we find that virtual product experience moderates the relationships between attitude toward presented product, attitude toward website and users' satisfaction. Our studyprovides important implications for e-tailers.
\end{abstract}

Keywords: 3D virtual product experience, 3D-quality, attitudetoward product, attitude toward website, satisfaction, Jordan

\section{Introduction}

Increasingly, online retailing has been growing over the business field and representing a new platform for both customers and retailers to exchange different kinds of values (Hasan, 2016; Yoh et al., 2003). As stated by recent report from OC\&C Strategy Consultants, PayPal and Google, in four highly developed countries namely the UK, US, Germany and China, online sales are more likely to enlarge to reach the level of $£ 645 \mathrm{bn}$ by 2018 in comparison with $£ 325$ in 2015(Telegraph, 2015). Worldwide, according to report published in Statista (2016) for the global online retailing sales for the period between 2014 to 2020, online retailing sales were able to account about $\$ 1.55$ trillion in 2015 and this number is expected to reach $\$ 3.4$ trillion by the end of 2019 .

Indeed, online retailing has revolutionised the way that customers interact with retailers (Algharabat and Shatnawi, 2014; Algharabat and Zamil, 2013;Parket al., 
2016; Kim et al., 2011; Liao and Keng, 2013). As a competitive necessity, firms have extensively integrated online shopping and online retailing as an essential platform along with traditional brick and mortar stores (Algharabat and Shatnawi, 2014; Lee, 2012). Essentially, retailer firms are looking to have more opportunities to better match their customers' needs and wants, and enhance customer's loyalty, and accordingly, contributing to their brands identity and profitability. Together, such platforms can contribute to the customers' daily life by facilitating access to products, services and information without time and place restrictions (Bilgihan, 2016; Hung et al., 2012; Kokkinoua and Cranage, 2013; Lin and Lian, 2008; Zhu et al., 2013).

However, the successful implementation of online retailers largely depends on their ability to contribute to customers' attitudes and satisfaction toward both presented products and website as well(Luan et al., 2016; Chen et al., 2015). This needs to have further understanding about the main predictors of customer's attitudes and satisfaction. Theoretically, website quality represents one of the most fundamental aspects considered by customers to evaluate either the interface orconsumers' entire online shopping experience (Algharabat and Shatnawi, 2014; Luan et al., 2016). Further, there is always a necessity to explore the role of experience especially virtual product experience on the customer perception toward all aspects related to online shopping (Algharabat, 2016; Algharabat, 2014a; Algharabat and Shatnawi, 2014;Overmars and Poels, 2015; Lee, 2012; Luan et al., 2016).

Within the context of online shopping, we noticed that previous literature (Algharabat and Shatnawi, 2014; Algharabat and Zamil, 2013) has employed individual constructs to define and conceptualise 3D-quality (3D-Q) based on a uni-dimensional construct. Therefore, previous research did not get the chance to have a comprehensive definition and measure of 3D-Q. Previous research either described the characteristics of 3D-Q without attempting to link them together, or investigated the main antecedents of 3D-Q. Therefore, based on the prior classifications and the antecedents of 3D-quality (Algharabat and Shatnawi, 2014; 
Algharabat and Zamil, 2013) we define 3D-quality as 'overall users perceptions of the excellence and effectiveness of an e-tailer's product presentation through its virtual store and often enhances information, system, authenticity, and enjoyment'. Moreover, this paper aims to answer the following research questions: (i) what are the main dimensions of 3D quality. (ii) How 3D-Q affects attitude toward product, attitudes toward website which in turn impact users' satisfaction. (iii) To what extent virtual product experience moderates such relationships.

Importantly, there is a quite few studies that have examined the related issues of online shopping and retailing in Jordan (Algharabat, 2016; Algharabat, 2014a; Algharabat and Shatnawi, 2014). Indeed, Jordan is one of the highly evolved countries in terms of technology and Internet subscribing; for instance, the number of Internet subscribers has reached 5.7 million users in mid-2015 with penetration rate $73.6 \%$. This is in addition to the fact that Jordanian people (Petra New, 2016). Further and according to IO, Hsoub (2016), the size of the Jordanian online relating sector was 0.21 billion. As well as, 1.6 million Jordanian customers who have used online shopping to purchase different kinds of products and services as reported by the same report of IO. Hsoub (2016). This means that online retailing in Jordan is a promising sector deserves further research and examination. Such studies of online retaking could provide more clues about the most important aspects that considered by customers in Jordan as a developing country especially in the fact that most prior studies of the related issues of online retailing have conducted within developed countries. Therefore, researchers were motivated to conduct their empirical study in Jordan.

\section{Literature on Three Dimensional Product Presentation Quality Website Quality}

Previous research (e.g., Ahn et al., 2003; Ho et al., 2012; Wolfinbarger and Gilly, 2003 ) posit that e-shopping quality refers to the overall consumer perceptions of the excellence and effectiveness of an e-tailer's product and/or service offering 
through its virtual store. Therefore, both the quality of website features and interface performance influence consumer's perception of Internet shopping.

Previous research assesses website quality based on interface or consumers' entire online shopping. For example, Loiacono, Watson, and Goodhue (2002) introduced the WebQual ${ }^{\mathrm{TM}}$ and identified twelve dimensions to measure website quality (informational fit-to-task, interactivity, trust, response time, ease of understanding, intuitive operations, visual appeal, innovativeness, flow/emotional appeal, consistent image, online completeness, and better than alternative channels). Kim and Stoel (2004) employed six dimensions to measure website quality (web appearance, entertainment, informational fit-to-task, transaction capability, response time, and trust). Yoo and Donthu (2001) introduced the SITEQUAL and measured website quality by conceptualizing four dimensions (ease of use, aesthetic design, processing speed, and security of personal and financial information). Zeithaml, Parasuraman, and Malhotra (2000) introduced the eSQ scale to measure website quality. The authors' scale consists of eleven dimensions (reliability, responsiveness, access, flexibility, ease of navigation, efficiency, assurance/trust, security/ privacy, price knowledge, site aesthetics, and customization/personalization). In line with Parasuraman, and Malhotra (2000), Parasuraman, Zeithaml, and Malhotra (2004) introduced the E-S-QUAL to measure online retail quality based on four dimensions (efficiency, fulfilment, system availability, and privacy).

Wolfinbarger and Gilly (2003) developed eTailQ, which measured consumers' perceptions of e-tail service quality. To develop the scale, the authors included eight factors (fulfilment/reliability, customer service, personalization, experiential/atmospheric, ease of use, informativeness, selection, and security/privacy) of website interface and marketing attributes. Wolfinbarger and Gilly's (2003) factors reduced into four dimensions: website design, security/privacy fulfilment/reliability, and customer service. Thus, it can be noticed that previous scales on website quality focused on the environment and interface (WebQual, SiteQual, eSQ), while the eTailQ scale focused on online retail service quality. 


\section{$3 D$ Product Presentation Quality}

Previous research on information system (IS) success model (DeLone and McLean 1992; DeLone and McLean, 2003) emphasises the importance of factors which often impact IS success (system quality, information quality, service quality, attitudinal outcomes and performance-related outcomes). However, within the context of online retailing, few attempts focused on measuring the quality of three-dimensional (3D) product presentation.

Previous research (Jiang and Benbasat 2005; Li et al. 2001; 2002; 2003; Suh and Lee 2005) on customer's online product experiences uses virtual reality (VR) techniques such as such 3D product presentation which enables consumers to visual inspection products which are simulated online with enlargement, zoom in or out on the product, rotate the product, and inspect the products functions. Li et al. (2001) defined virtual product experience (VPE) which is accompanied by 3D product presentation as the psychological and emotional states which consumers have once interact with products in a $3 \mathrm{D}$ environment. Therefore, according to $\mathrm{Li}$ et al. $(2001,2002,2003)$ high quality of 3D product presentation often enhances consumers' ability to feel, touch, and try products on electronic websites. Thus, the main goals of the $3 \mathrm{D}$ product presentation are to help consumers to understand more about the product functionality, product performance and it allows consumers toevaluate the superiority of the product features. Furthermore, 3D product presentation often enhances consumers' attitudes, knowledge and purchase intentions (Hoch and Deighton 1989; Jiang and Benbasat 2005; Li et al. 2001; 2002; 2003; Suh and Lee 2005).

Li et al. (2001), in a qualitative study, identified five critical characteristics of 3D product presentation (active process, presence, involvement, enjoyment, and affordances) the authors posit that the higher the characteristics of 3D product presentation, the better the virtual experience derived from navigating a 3D product. Even though the authors identified (tele)presence as one factor which impact the quality of $3 \mathrm{D}$ experience, the authors were not able to institute any causal linkages with the protocol methodology. Therefore, Li et al. (2002) measured 3D VPEusing the notion of presence. The authors posit that high levels 
of media characteristics considered the main enabler of the quality provided by the $3 \mathrm{D}$ product experience. Many researchers used the notion of telepresence to conceptualize consumers' experiences in online environments. For example, Coyle and Thorsen (2001) assert that high interactivity and vividness levels increase perceived telepresence of websites. Using an online advertising context, Klein (2003) posit that previous research (Coyle and Thorson, 2001; Novak, Hoffman, and Yung, 2000) did not study virtual product experiences but rather virtual websites experience. Therefore, Klein (2003) investigated the notion of telepresence with its underlying dimensions (user control and media richness) as the main enablers for VPE. The author investigates the impact of VPE (telepresence) on consumer responses (brand beliefs and attitudes) and finds that high level of user control and media richness enhances the quality of $3 \mathrm{D}$ virtual product.

Hopkins, Raymond and Mitra (2004) argued that Klein's (2003) study considered one of the few studies which investigated the impact of perceived telepresence, in an online advertising context. However, Hopkins et al. (2004) posit that Klein's (2003) study does not examine the role of involvement (as a characteristic of VPE) as recommended by $\mathrm{Li}$ et al.'s (2001) study and its relationship with perceived telepresence. The authors, therefore, measured VPE depending on the notion of telepresence which has been measured based on media richness but not interactivity. Therefore, according to Hopkins et al. (2004), high media richness quality is the main enabler of 3DVPE. Further, the authors did not consider involvement as a predictor forVPE, instead they test it as a moderator between perceived telepresence and consumer responses (i.e., attitude toward the advertisement, attitude toward the brand, and purchase intention).

Toward this end, Jiang and Benbasat (2005) classified VPE technology into two types; visual control (e.g., software which allows consumers to move, rotate, and zoom in and out a product's image, see it from different angles, distances, and perspectives) and functional control (e.g., software which enables consumers to sample different functions of products through their computers). Examples of functional control are the ability of the $3 \mathrm{D}$ product presentation to emit alarm 
sounds, through the movement of particular parts of the product, or through changes in the appearance of the product. Therefore, according to the authors, functional control includes how the $3 \mathrm{D}$ product presentation works, while visual control relates to how the 3D product presentation looks (i.e., the 3D product form). Moreover, the authors investigated the impact of visual and functional controls (as the main enablers of VPE) on products that have 3D visual appeal and contain varied functionality information. The authors find that high quality of visual and functional controls lead to higher perceived diagnosticity (the extent to which consumers believe the shopping experience is helpful to evaluate products) and flow (computer users' affective responses to computer usage, characterizing playfulness and exploration as defining characteristics of human-computer interactions).

Unlike Jiang and Benbasat's (2005) study which focused on the enablers of VPE using 3D product presentation, Jiang and Benbasat (2007a) investigated the impact of functional mechanisms (measured by interactivity and vividness of the online presented product) including static images, video-with-narration, videowithout-narration, and functional control. Jiang and Benbasat (2007a) concluded that $3 \mathrm{D}$ product presentation, as a type of functional mechanism should be designed with high level of both interactivity (the way that consumers interact with $3 \mathrm{D}$ product) and vividness (the representational quality of how product information is conveyed to consumers) to achieve the virtual experience using $3 \mathrm{D}$ product presentations. However, Jiang and Benbasat (2007a) study did not employ the notion of telepresence, which prior research (Steuer 1992) has suggested to measure the enablers of VPE. The authors focused on vividness and interactivity as the main enablers of VPE. The authors justify this because the notion of telepresence seems to be less relevance and thus, it deals with the feeling of "being there" in a virtual environment (Steuer, 1992). However, Jiang and Benbasat (2007a) posit that their research centres on individual products, rather than an environment. Therefore, the authors replaced the notion of telepresence with the notion of compatibility (users' perceptions of the extent to 
which a product experience is similar to or consistent with their physical product experience).

Algharabatand Dennis (2010) focused on users' ability to control the content and form of the 3D product presentation (interactivity), and their ability to change the colour of the 3D product presentation (vividness) as the main enablers of VPE. Algharabat and Shatnawi (2014) find that perceived usefulness (conceptualised as the degree to which a person believes that using 3D product presentation would enhance his/her shopping performance), perceived enjoyment and perceived social presence (conceptualised as having a sense of human warmth and sociability) are the main enablers of 3D-quality (3D-Q). Algharabat and Zamil (2013) posit that 3D-quality is enhanced by two enablers; 3D product presentation information quality and 3D product presentation system quality.

Therefore, it could be noticed that previous studies treated 3D-Q as a black box. For example, (i) we believe that previous studies still lack the chance to develop a comprehensive definition of 3D-Q and thus the main dimensions of 3D-Qhave not been investigated in a comprehensive way. All the previous attempts focused on defining the enablers of VPE created by 3D product presentation but not the main dimensions which impact the quality of the $3 \mathrm{D}$ product presentations. (ii) We noticed that extant literature on the 3D-Q area has used individual constructs to measure it. Notwithstanding, we believe that the dimensions of 3D-Q are still questionable. For example, should researchers depend solely on notions such as interactivity, vividness, visual control, functional control, functional mechanism, 3D information quality, 3D system quality, 3D usability and 3D enjoyment to measure 3D-Q or should they use a combination of them? Therefore, we aim to empirically answer this question.

To that end, we believe that previous literature in 3D-Q is very rare; accordingly, we explore the 3D-Q of online shopping websites. This argument comes after that 3D product presentation is often a part of online services provided by online retailers and, thus, the 3D-Q enhances the quality of the online shopping website. Recent studies have shown that website elements such as product visualisations, layout and colour may impact consumer evaluation of website quality (Algharabat 
and Dennis, 2010; Valdez and Mehrabian, 1994; Van Rompay et al., 2005; Zhang et al., 2006).

Based on the previous categorizations of the antecedents of 3D-quality (Algharabat and Shatnawi, 2014; Algharabat and Zamil, 2013), we propose the following definition of 3D-quality 'overall user's perceptions of the excellence and effectiveness of an e-tailer's product presentation through its virtual store and often enhances information quality, system quality, authenticity, and enjoyment'. We believe that this definition has not been tested in the earlier research, and, thus we expect that measuring 3D-Q based on the proposed definition as well as testing the moderating impact of virtual product experience will be the contributions of this research, an issue that has not been tested in any previous empirical study. Moreover, this paper aims to analyse how 3D-Q affects attitude toward product, attitudes toward website which in turn impact users' satisfaction, as well as to find out to what extent VPE moderates such relationships, another issue that has not been tested in any previous empirical study.

\section{Research Model and Hypotheses}

\section{Dimensions of the 3D-Quality}

Based on the recent studies (Algharabat and Shatnawi, 2014; Algharabat and Zamil, 2013) which measured 3D-Q based on its antecedents, we believe that the quality of $3 \mathrm{D}$ product presentation should be treated as a multi-dimensional construct rather than aunidimensional one.Therefore, it was important to capture the fundamental dimensions of the $3 \mathrm{D}-\mathrm{Q}$ in order to enable customers to properlyvisualizethe targeted product, and accordingly, to help them evaluate the

presented product and to make online purchase easier. Previous studies(e.g. Algharabat and Shatnawi, 2014; Algharabat and Zamil, 2013) on 3D-Q define and conceptualise 3D-quality based on one of the following constructs: 3D information quality, 3D system quality, perceived usefulness, perceived enjoyment and perceived social presence. However, the previous research did not attemptto produce a comprehensive combined scale, based on the above constructwhich can be used to measure the 3D-Q within the context of online 
retailers. Accordingly, and as seen in Figure 1, 3D information quality, 3D system quality, 3D authenticity, and 3D enjoyment all were integrated as 3D-Q scale. The proposedscale in the current study, hopefully, will provide a clear picture to readers regarding the important dimensions of 3D-Q. We decided to include the above dimensions for the following reasons; (i) in line with previous studies, we adopted the notions of information quality and system quality to reflect the content and context of the 3D product presentation. (ii) We included the notion of authenticity to reflect the psychological aspect of users while dealing with the $3 \mathrm{D}$ product presentation. (iii) The enjoyment construct has been used to reflect the affective aspect which is expected to enhance hedonic users to navigate the $3 \mathrm{D}$ product presentation. To that point, we believe that the proposed dimensions not only cover what previous researchers investigated, but also they added more dimensions from different foci. Additionally, the proposed scale was adopted in the current study to verifythe causal paths between 3D-Q, attitude toward presented product and attitude toward website, which in turn influence consumers' satisfaction (see Figure 2).

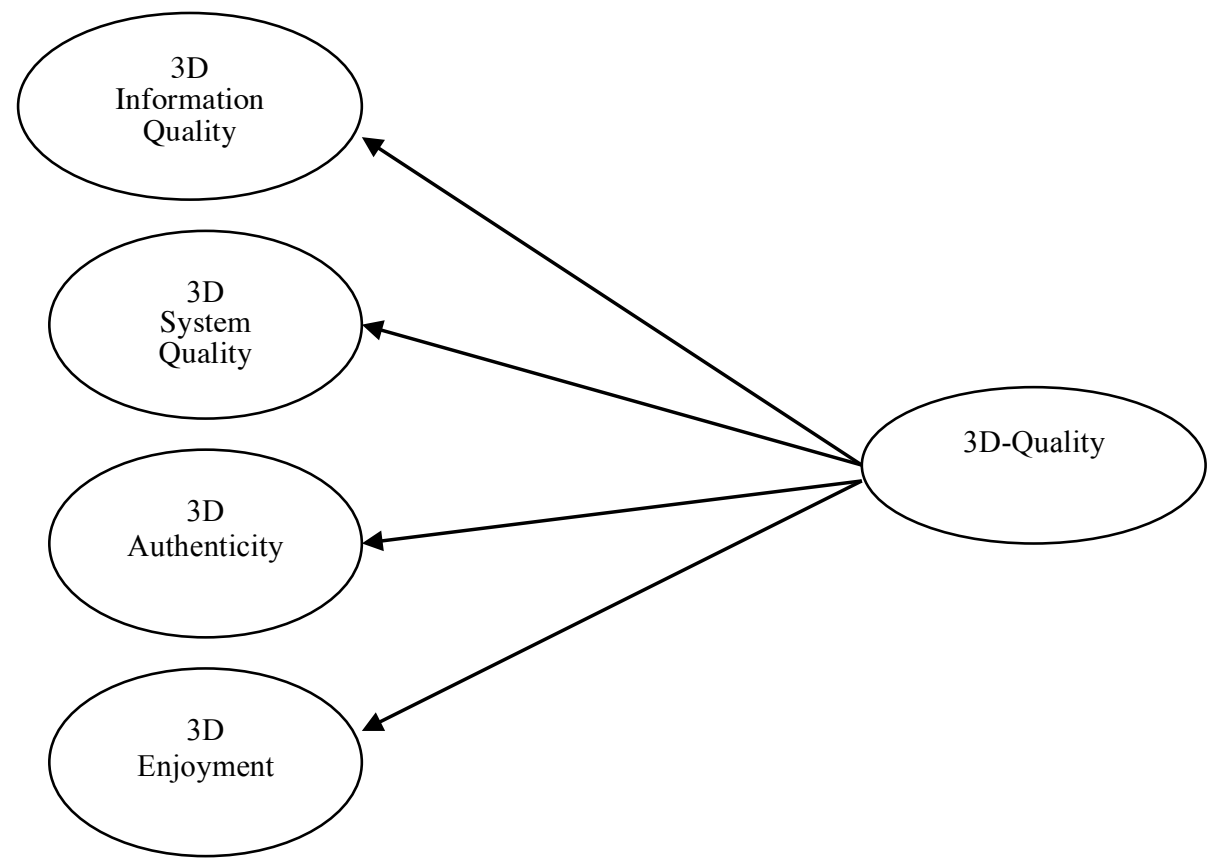

Figure 1.3. D-Quality Combined Scale: A Second Order CFA

Adapted from Algharabat and Dennis (2010); Algharabat and Zamil (2013);DeLone and McLean (1992, 2003), Fiore et al. (2005); Li et al. (2002, 2003) 


\section{D Information Quality}

Consumers often seek to have information about product. Thus, the Internet considers one of such sources, which often enhance consumers' virtual experience (Klein, 2003) in which consumers often interpret the web information similar to information obtained from their offline direct experience (Li et al., 2002).

DeLone and McLean (1992) define information quality as user's perception of the quality of outputs, which information system presented. Furthermore, the authors posit that relevance of information, timeliness of information, and accuracy of information are the main elements that should be used to measure information quality. Huh et al. (1990) assert that accuracy, completeness, consistency and currency of presented information are main dimensions to measure information quality. In the same context, Nelson et al.'s (2005) study adds a fifth element to the Huh et al.'s (1990) study, namely format, which related to the presentation layout of information outputs. However, McKinney et al.'s (2002) research is centered on website quality of information. To measure information quality, Zhilin et al. (2005) relied on usefulness of content, reliability, currency, accuracy, and adequacy of the presented information. Doll et al. (1994) assert that content, accuracy, format, ease of use, and timeliness are the main antecedents to measure information quality.

Jiang and Benbasat (2005) investigated the impact of visual control on website diagnosticity. The authors posit that visual control which allows consumers to view the $3 \mathrm{D}$ product presentation from different angles, to enlarge, to rotate, to move, and to zoom in and out a product's image, provides information about the presented product and thus this provide consumers with vivid information about the product. The authors assert that virtual control (measured with both virtual control and functional control) which depends on multimedia technology reflects the notions of interactivity and vividness (the quality of product presentation) which previous research (Li et al., 2002, 2003; Klein, 2003) employed to measure their impact, as enablers of VPE, and thus it is helpful to users to get relevant product information. The authors argued that more vivid 3D product presentation provides consumers with more information, more ability to examine the product, 
stimulates more sensory channels, allows consumers to realistically perceive the product, and thus improves consumers' productunderstanding.

Li et al. (2002) posit that 3D product presentation enhances consumer information due to its characteristics and thus increase product knowledge. Li et al. (2003) assert that $3 \mathrm{D}$ product presentation enhances information seeking. Jiang and Benbasat (2007a) assert that using interactive technologies such as 3D product presentations enhance consumer's ability to understand more about information presented in the $3 \mathrm{D}$ presentation due to the ability of such technology to facilitate user's ability to "feel, touch, and try" the presented products (Jiang and Benbasat 2005, Li et al. 2001, Suh and Lee 2005). The authors stated that $3 \mathrm{D}$ product presentation enhances functional mechanismswith its main enablers; vividness and interactivity.

Jiang and Benbasat (2007b) relied on the theories of multimedia learning and active learning to investigate the impact of four types of product presentations (static pictures, videos-without-narration, videos-with-narration, and VPE) onconsumer actual knowledge and perceived knowledge. The authors posit that VPE which requires active learning and trail allows consumers to virtually feel, touch, and try products and it often enhances consumers understanding of the product features and performance. The authors assert that using $3 \mathrm{D}$ product presentation enhances website diagnosticity (defined as consumers' perceptions of the extent to which a particular website is helpful for them to understand products in online shopping (Jiang and Benbasat 2005; Kempf and Smith 1998).

Algharabat and Zamil (2013), define 3D information quality as the extent to which the $3 \mathrm{D}$ provides accurate, relevant, complete and precise information regarding the presented product. The authors state that $3 \mathrm{D}$ information quality should reflect the content and form of the presented product, which users look for. Furthermore, the authors posit that such information should help users to understand and evaluate the quality and performance of products sold online. Algharabat and Shatnawi (2014) investigated the impact of perceived usefulness, perceived social presence and perceived enjoyment on quality $3 \mathrm{D}-\mathrm{Q}$. The authors employed 3D technology in the online apparel industry and tested their model 
using My Virtual Model ${ }^{\mathrm{TM}}$ technology. The authors find positive relationships between perceived usefulness and 3D quality. Therefore, we believe that information quality is a main dimension for the $3 \mathrm{D}$-quality.

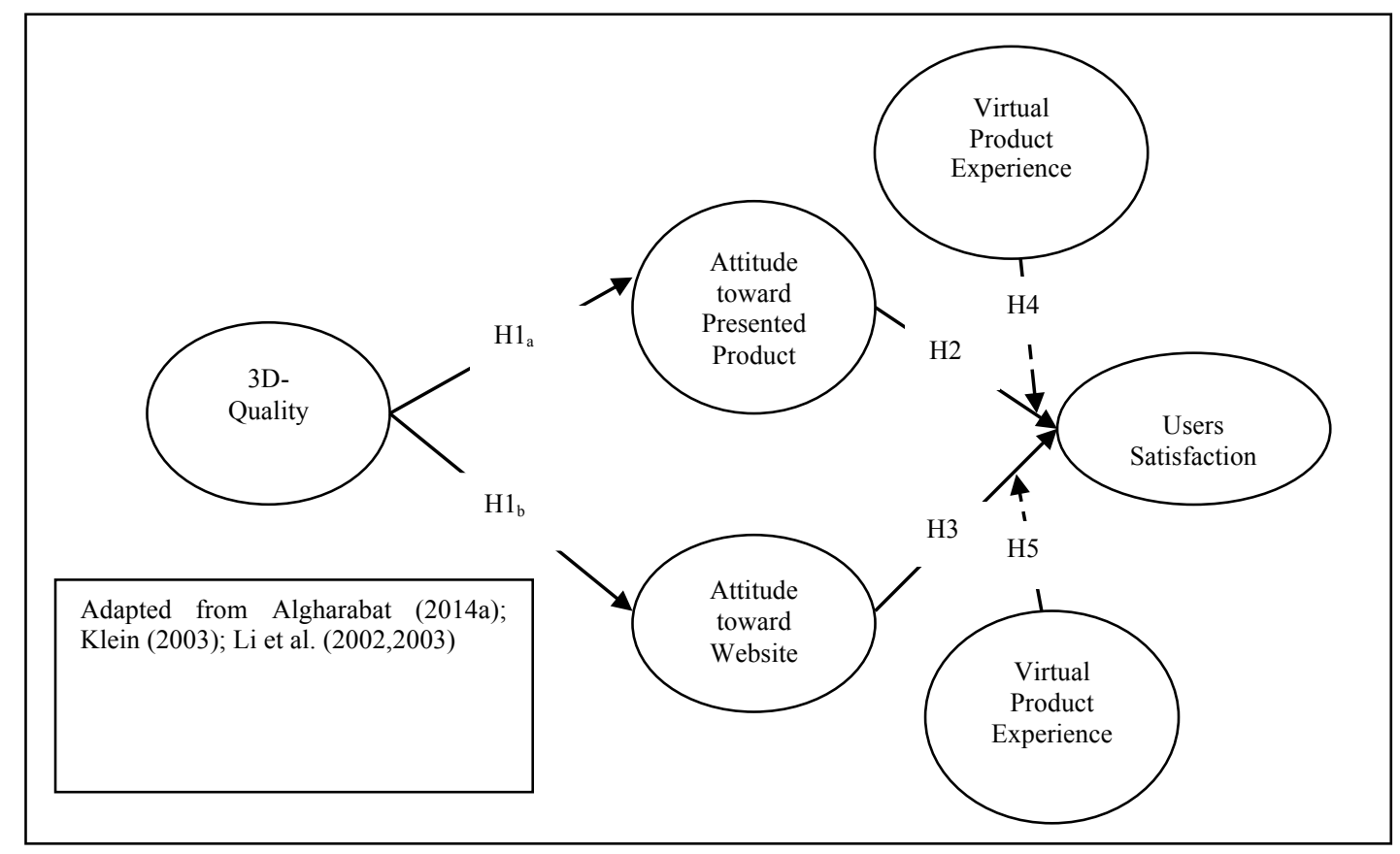

Figure 2. Conceptual Framework

\section{D System Quality}

DeLone and McLean (1992) define system quality as individuals' perceptions of a system's overall performance. DeLone and McLean (2003) measured system quality via attributes such as ease of use, functionality, reliability, data quality, flexibility, and integration. Previous research studies (e.g., Eisenmann and Pothen, 2000; Nelson et al., 2005) assert the importance ofusability, visual design and ease of navigation as main elements of system quality.

The notion of interactivity has attracted the attention of many scholars (Sundar, 2004). Therefore, this concept has been defined and conceptualized in different ways (Sundar, 2004). For example, within the context of virtual reality, Steuer's (1992, p.84) define interactivity as "the extent to which users can participate in modifying the form and content of a mediated environment in real time".Therefore, according to previous research (i.e., Ariely, 2000; Klein, 2003) consumer ability to modify the VPE which is capsulated in the $3 \mathrm{D}$ product 
presentation is explained by user control. $\mathrm{Xu}$ and Sundar (2014) defined interactivity of e-commerce website based on its functional features (e.g., flipping the product, sliding the product, rotating the product). The authors posit that the presence of such technology features, interface tools, allow users to interact with the interface or the system (Sundar, 2007). Sundar, Kalyanaraman and Brown (2003) assert that such interface tools often enhance information exchange between the user and the interface. Fiore et al. (2005) argue that 3D product presentation provides consumers withmany benefits such as; facilitating communications with the product, information customization, entertainment, and image manipulation.

Kim, Fiore and Lee (2007) indicate that 3D product presentation provides high level of image interactivity technology due to its ability to enlarge front views of products, zoomed-in or out, illustrate the presented products with different angles and from different distances. All these interactive features make consumers feel more control over the manipulationof the product image.Schlosser (2003) defined a particular type of interactivity, namely, object interactivity. The author argues that object interactivity focused on product features, but not website and found that object interactivity helps consumers to formulate mental imagery about the product consumption. Jiang and Benbasat (2005) have projected that consumers' ability to manipulate $3 \mathrm{D}$ product presentation allowsthem to control perspectives anddistances of product's appearance.

Algharabat and Zamil (2013) define 3D system quality as the extent to which the $3 \mathrm{D}$ is easy to use, user friendly, and well designed to navigate the presented product. Kim and Forsythe(2009) reflected 3D system quality by focusing on usefulness and ease of use of the presented products. Fiore and Jin (2003) posit that consumers' ability to manipulate $3 \mathrm{D}$ product presentation (i.e., to check the side and back views of the 3D product) often enhances visual sensory information. Kim et al. (2007) indict the positive relationship between 3D virtual model visual design and user's involvement with the presented product. Algharabat and Dennis (2010) postulate the importance of ease of use and control of $3 \mathrm{D}$ product presentation to enhance VE. Jiang and Benbasat (2007a) assert the 
importance of 3D interactivity in creating a diagnostic 3D product presentation. Therefore, we believe that system quality is a main dimension for the $3 \mathrm{D}$ quality.

\section{D Authenticity}

In order to measure the quality of $3 \mathrm{D}$ product presentation, the presented products should be authentic. Algharabat and Dennis (2010) employed the notion of 3D authenticity to measure 3D VPE. According to Algharabat and Dennis (2010), 3D authenticity capturesconsumers' psychological statein a way that customers perceivethe virtual objectscomprised in the $3 \mathrm{D}$ over the virtual area as actual objects.This, in turn, provides customers withthe requested information regarding the products aspects clearly, and accordingly, empowering them to effectively understand and assess the significant dimensions of the 3D-Q and performance of the products that are promoted and traded electronically. Algharabat and Dennis (2010) assert that using the notion of telepresence does not reflect reality of the online 3D product presentation. Therefore, the authors defined and conceptualized VPE based on authenticity (consumers' sense of being in a simulated real world) of the 3D presentation depending on its enablers (control and vividness). Thus, 3D-Q should enhance users' ability to simulate their offline experiences. Therefore, we believe that authenticity is a main dimension for the 3D quality.

\section{D Enjoyment}

The 3D enjoyment reflects users' enjoyment once navigating the $3 \mathrm{D}$ product presentation. The importance of this dimension has been posited in previous literature. For example, Shih (1998) posits that enjoyment is one of the main outcomes produced by navigating 3D product presentation. Li et al. (2001, 2002, 2003) postulate that feelings of pleasure produced by 3D product presentation often enhance users' evaluations of VE. Li et al.'s (2001) qualitative study shows that consumers ability to virtually modify products (i.e., changing product coloring) increase users' enjoyment. Fiore et al. (2005) asserted that high level of 3D product presentation often enhances experiential values. Kim and Forsythe (2007) posited the ability of 3D product presentation to enhance participants' 
hedonic benefits. Algharabat and Dennis (2010) asserted that authenticity of the $3 \mathrm{D}$ product presentation leads to enjoyment. Therefore, we believe that enjoyment is a main dimension for the $3 \mathrm{D}$-quality.

\section{D-Quality, Attitudetoward Product Presentation and Attitude toward Website}

Jiang and Benbasat (2005) define attitude toward products as consumers' overall evaluations of products. Therefore, we measured attitude toward 3D presented product as affective and cognitive construct. Doing so would reflect users'believe that a 3D product presentation is an authentic one and, thus, will reflect their offline experience (i.e., the direct experience) (Jin, 2009;Kempf and Smith 1998; Smith, Feinberg, and Burns 1998; Smith, 1993). As a result, consumers will perceive product information thoroughly and favourably. 3D-Q often provides users with visual information (Kim and Lennon, 2008), which influence user's affective attitude and verbal information, which is expected to impact their cognitive attitudes and vice versa (Kim and Lennon, 2008).

Li et al. $(2002,2003)$ assert that 3D product presentation has a positive influence on brand attitudes, product knowledge and purchasing intention. Suh and Lee (2005) reported that a 3D product presentation has a significant impact on attitude toward product. Fiore and Jin's (2003) study reveals that using a highly interactive 3D product presentation has a positive influence on customers' attitude. Klein's (2003) research showed that high levels of users control (interactivity) and media richness (vividness) have a significant effect on the intensity of beliefs and attitudes. Coyle and Thorsen (2001) found that high level of vividness resulted in stronger attitudes toward website. Hopkins et al. (2004) state that perceived telepresence significantly affects attitude toward the brand and attitude toward the advertisement. Chen and Tan (2004) find that customer service quality directly influences attitude toward using virtual stores. Algharabat and Zamil (2013) find a positive relationship between 3D quality and attitude toward the presented product. Fiore et al. (2005) find that the interactivity nature of 3D product presentation enhances consumers' global attitudes toward online stores. Algharabat and Abu-ElSamen (2013) assert the importance of 3D product 
presentation to enhance users' attitude toward the product and the website. Algharabat (2014b) asserts that 3D product presentation impacts users' attitude toward online retailer. Algharabat (2016) posits the positive relationships between 3D product presentations and attitude toward websites (e.g., knowledge and entertainment). To that point we believe that building positive relationship between 3D-Q and attitude (toward the presented product and the website) is vital for e-retailers. Attitude toward the website will attract the attention of users and increase their cognitive and affective attitude toward the web which might end up with searching for more products and hence increase their purchase intensions and actual behavior. Therefore, we hypothesise:

H1a: There is a positive relationship between $3 D-Q$ and attitude toward presented product.

H1b: There is a positive relationship between $3 D-Q$ and attitude toward website.

\section{Moderating Role of Virtual Product Experience on the Relationships between Attitude and Users Satisfaction}

Previous research on VPE defines it based on different constructs (Serrano et al., 2013; Overmars and Poels, 2015). For example, Jiang and Benbasat (2005) defined and conceptualized VE based on perceived diagnosticity and compatibility. Algharabat and Dennis (2010) relied on the notion of authenticity (physical simulation of consumers' offline experience) to define VPE. Other scholars (Li et al., 2002; 2003; Klein, 2003; Suh and Lee, 2005) centred their efforts on the notion of telepresence (users' ability to be transformed into another area).

To that end, Algharabat (2014a) revised the extant literature and find a gap in conceptualizing and modeling VPE for the online retailers. The author suggests a combined VPE scale. Algharabat's (2014a) study based on previous research (Algharabat and Dennis, 2010; Klein, 2003; Overmars and Poels, 2015; Li et al., 2001, 2002, 2003; Jiang and Benbasat, 2005, 2007a, b) and definesVPE based on a multidimensional scale consists of diagnosticity, authenticity, compatibility, flow and enjoyment. Furthermore, Algharabat (2014a) argue that VPE reflects the 
direct experience, which users can find offline and that VPE helps users to imagine the illustrated product properly.

Therefore, we employed the construct of VPE, as conceptualized by Algharabat (2014a), as a moderator in this study. To the best of authors' knowledge, this is the first study, which investigates the moderating role of VPE on the relationship between attitude toward the presented product, attitude toward the website and users' satisfaction. We tried to revel the previous literature on the importance of online experience as a moderator. However, we find that previous literature measured online consumer experience rather than VPE (Gefen et al., 2003; Hoffman and Novak, 1996; Novak et al., 2000; Venkatesh et al., 2003). Further, previous literature examined online experience based on two levels (i.e., high or low). However, this research measured VPE as a continuous construct.

The existing literature (e.g., Petty, Cacioppo, and Schumann, 1983; RatneshwarandChaiken, 1991) on user's attitude indicates that the consumer's experience moderates attitude and the process by which it is formed. Therefore, it is expected that such overall evaluation and strengthsto be influenced by the level of consumer experience (Oliver, 1996). Fishbein and Ajzen (1975) posit that an individual's positive experience will have an important effect on his/her behavior. Previous theories (i.e., attitude-formation theories) such as the elaborationlikelihood model (central route and peripheral route, Petty and Cacioppo, 1986; Petty et al., 1983) and the heuristic-systematic processing model (systematic process, heuristic process, Chaiken, 1980) emphasised on the importance of consumer experience to determine his/her attitude and that consumer's ability (i.e., knowledge and experience according to Alba and Hutchinson, 1987) and motivation impact the individual's attitude-formation. Therefore, once a person level of ability and motivation is high, then it is highly and likely to employ the central route or systematic process. Therefore, this approach ends up with a strong influence on behaviour.

On the other hand, ifaperson level of ability and motivation is low or even lack both of them, then his/her attitude is formulated based on the peripheral route or heuristic process. The elaboration-likelihood model and the heuristic-systematic 
processing model offer reasons about the variation in strength of the relationship between attitude and behaviour. Therefore, it is expected that VPE moderates the relationship between attitude toward the presented product and users' satisfaction. Previous research investigated the moderating role of online experience. For example, Rodgers, Negash and Suk (2005) investigated the moderating role of online experience (conceptualised as knowledge stored in memory and decisionmaking ability) between online satisfaction and online loyalty. The authors find the relationship between online satisfaction and online loyalty is stronger for consumers with more online experience than for consumers with less online experience. Pappas et al. (2014) establish that experience is important in forming customers' perceptions, regarding their expectations from online retailers. Zhou et al. (2007) confirmed that higher experience increased satisfaction with online shopping. Gefen et al. (2003) tested the moderating effect of experience in online stores. Rodgers, Negash and Suk's (2005) study find that the relationship between online satisfaction and loyalty is moderated by online experience. The more experienced the users are, the stronger the relationship would be.

However, Yoon, Hostler, Guo and Guimaraes (2013) found that consumer online shopping experience does not have a significant effect on the relationship between customer satisfaction and customer loyalty. Venkatesh et al. (2003) identify user experience as a factor, which moderates the effect of effort expectancy on behavioural intention. Kwak, Fox, and Zinkhan (2002) posit that the adoption of e-commerce is influenced by the previous experience of individuals with the Internet. Thus,

H2: There is a positive relationship between attitude toward presented product and users'satisfaction.

H3: There is a positive relationship between attitude toward website and users' satisfaction.

H4a: Virtual product experience positively moderates the relationship between attitude toward the product and users' satisfaction.

H4b: Virtual product experience positively moderates the relationship between attitude toward the website and users' satisfaction. 


\section{Research Method}

\section{Stimuli and Interface Design}

In order to validate the conceptual model and to verify the research hypotheses, we followed Algharabat (2014a) and Suh and Lee's (2005) and Park et al.(2008) methodologies in this research.Therefore, the researchers designed and customized an online shopping retailer which sells laptop.

We designed the website in a way that helps customers to monitor the content and formof the 3D.Indeed, byclicking on the 3D presented products, users were freely able to enlarge, minimize and rotate the $3 \mathrm{D}$ product presentations. Users were also allowed to select laptop's colour that they would like to see.Besides, we provided participants withthe related information of the presented 3D laptop features(i.e., weight, size, visual clarity, price, warranty, special effect features)so the features of the $3 \mathrm{D}$ were prepared to contribute to the way that customers can imagine and visualize the presented products properly, and accordingly, contributing to the customers' online shopping experience.

In fact, participants did not have anidea or previous knowledge about the designed website of the current study prior to using it. They even were not given any information regarding the brand name of the products sold in the website.Therefore, the researchers successfully prevent the influence of users' prior attitudes and experience as suggested byAlgharabat and Dennis (2010) and Fiore et al.(2005).Refer toAppendix A for screen shot of the 3D laptops.

\section{Justifications for Using the Stimuli}

In fact, we choose laptops as the main stimulus on this research due to their ability to be assessed, using 3D interface,based on significant featuresas well as their ability to be evaluated based on both kinds of features: experience (i.e. weight, visual clarity, and size)and search (i.e. special effect features, price, and warranty).Over the prior literature, Algharabat (2014a); Algharabat and Zamil(2013); Algharabat and Dennis(2010); Li et al.(2001); Suh and Lee(2005) have also adopted laptop products in their studies. Such of that, applying 3D 
laptops was justified by $\mathrm{Li}$ et al. (2001) due to the fact that such product categories have an influence on the consumers'behavioursas well as their attitudes over the online area. In his study, Algharabat (2014a) also supported that either the customers' penchant or customers' orientationare largelyaffected by 3D laptops. Customers' satisfaction was noticed by Algharabat and Zamil(2013) to be affected by 3D laptops. Thus, 3D laptops were found to be appropriate product category to be tested and introduced to the current study' participants.

\section{Sample and Procedures}

In spite of the fact that probabilitysampling techniques (i.e. simple random sampling; the stratified sampling technique) characterizes with a higher degree of generalizability in addition to the lower extent of sampling bias, current study found applying such kind of samples inapplicable (Bhattacherjee, 2012). This is attributed to the fact that conducting such sampling technique requests number of conditions that do not exist in the current study population. Such of these conditions, this study was not able to find an inclusive and updated list of the online shoppers in Jordan. Accordingly, conductingany kind of random sampling techniques was not achievable (Castillo, 2009; Dwivedi et al., 2006). This, in turn, makes using convenience sampling technique more applicable in the current study (Bhattacherjee, 2012; Dwivedi et al., 2006; McDaniel and Gates, 2006). Additionally, by using convenience sampling, researchers were able to approach alarge number of Jordanian online shoppers with less time and cost (Bhattacherjee, 2012; Castillo, 2009; Wilson, 2006).

Moreover, over the prior literature, large number of studies have adopted the convenience sampling approach to reach the targeted respondents (i.e. Bryman and Bell, 2007; Castillo, 2009; Dean, 2008; Purwanegara et al., 2014; Wilson, 2006). Therefore, this research employed a non-student sample to conduct this research.

A sample size of 410 was applied to capture the requested data for the purpose of the current study.The sample was gender-balanced, half of the participants are males and the second half of them is female.The vast majority of participants were noticed withinthe age group of 24 and 50 years old. The largest part of those 
participants (98\%) stated that they have used online shopping, but they have not purchased form an online retailer after seeing their 3D presentations. To verify the generalizability of the current study results, a non-response bias test suggested byArmstrong and Overton's(1977) method of comparison was conducted via testingthe late responses with the early ones.The responses for both groups were found to be non-statistical different from each other (less than 0.05 ; for system quality, information quality, authenticity, enjoyment, attitude toward product presentation, attitude toward website, users' satisfaction and VPE).Accordingly, we believe thatthere is no concern regarding the non-response bias for the data collected in the current study.

The empirical data of the current study was collected over the Jordanian context, Middle East. As Arabic is the main language in Jordan, back translation method suggested by Brislin (1976) was conducted to avoid any problem for cultural and language problems.A small sample size comprising a number of staff who works in a public university in Jordan was employed to do a pre-test forthe data instrument of the current study (Bhattacherjee, 2012; Sekaran, 2003).

To identify the needed time for navigating each 3D product site, we adopted Zajonc's (2001) method which limits the navigation time up tofive minutes.At the beginning,participants were allowed to have a number of practice trialsto get used with the targeted websites. Then, the participants were told that the main aim of the current study is to examine the online shopping experience using a number of online retailers. After that participants were invitedto visit one of the website and to fill up the given questionnaire.

\section{Pre-test}

So as to empower potential users to virtuallyexperience the online products, two levels: high versus low were adopted to manipulate 3D-Q. Researcherscategorize high level of 3D-Q by having a high level ofinformation quality, system quality, authenticity and enjoyment. On the other hand, we categorize the low level of 3DQ to be with low level of information quality, system quality, authenticityand enjoyment. Accordingly, two 3D sites were established. In the first one, users 
were allowed to enlarge, minimize and rotate the laptop as well as to watch many components of these products using many colours(high level of information quality, system quality, authenticity and enjoyment).

Further, users were able to capture all the needed information regarding these laptops (i.e. size, prices). In the second website, users were not able to capture the prior features (i.e., enlargement, zoom out, rotating the product, seeing different colours and having the required information) and thus this website represents low level of information quality, system quality, authenticity and enjoyment. A pretest was conductedwith a number of non-student convenience sample $(n=50$, staff at public university in Jordan). Using 7-point scale, those participants were invited to rank several 3D-Q according to their information quality, system quality, authenticity and enjoyment of laptops.

Manipulation checks were employed to judge if the participants observe the variation between different conditions for each construct either high or low. Followed by each level, participants were presented the forthcoming statements [i] The3D provides accurate information about the laptops, [ii] The 3D provides relevant information about the laptops, [iii] The 3D provides complete information about laptops, [iv] The 3D provides precise information about laptops, [v] The 3D is easy to use, [vi] The 3D is user friendly, [vii] The 3D is well designed to navigate, [viii] The $3 \mathrm{D}$ is convenient to access, [ix] The 3D presentation is helpful for me to understand the quality of the product, [x] The 3D lets me feel like I am holding a real laptop and rotating it, [xi] The 3D lets me feel like I am dealing with a salesman who is responding to my orders, [xii] The 3D lets me see the laptop as if it was a real one, [xiii] I find my experience with this website interesting, [xiv] I find my experience with this website enjoyable, [xv] I found my visit to this website entertaining, and [xvi] I found my visit to this website pleasant.

According to the outcomes of thepre-test, participants were observed to be able to perceive 3D-Q at different levels. Indeed,3D laptop website characterized by a high degree ofinformation quality, system quality, authenticity and enjoyment was perceived as being significantly providing a high qualityin comparison to the $3 \mathrm{D}$ 
laptop website with low level of information quality, system quality, authenticity and enjoyment $\left(\mathrm{M}_{\text {high }} 3 \mathrm{D}-\mathrm{Q}=6.55, \mathrm{M}_{\text {low }} 3 \mathrm{D}-\mathrm{Q}=1.44 ; \mathrm{F} 1,49=116.4\right.$, p $<0.001)$.

\section{Construct Operationalisation}

At the beginning, researchers were telling the staple respondents that the current research aims to measure 3D-Q in online retailers. Seven point Likert scale ranging from"strongly disagree" to "strongly agree" was used to measure the scale items adopted in the current study questionnaire (see Table 1).

The authenticity (AUTH)construct was measured by four items extracted from the scale proposed by Algharabat and Dennis' (2010). Information quality (INFO) and system quality (SQ) were tested by four items for each of one of them and these items based on scale proposed by Algharabat and Zamil (2013) and adopted from DeLone and McLean (1992, 2003). Enjoyment (ENJ) was tested using four items formulated in a modified version based on scale ofKoufaris (2002) and Ghani and Deshpande (1994). A scale proposed byVan der Heijden et al. (2001), Grazioli and Jarvenpaa (2000), and Coyle and Thorson (2001) was used to test customers' attitudes toward products (ATPP).

For attitude toward the website (ATTW), we used three items from Almendrosand Garcia (2015) and Castaneda et al. (2009). To measure satisfaction (SAT) we used three-item modified version of McKinney et al. (2002), Wixom and Todd (2005) and Algharabat and Zamil (2013). Finally, to measure virtual product experience, we used Algharabat's (2014a) four-item scale.

Table 1: Research Construct Operationalisation

\begin{tabular}{|l|l|}
\hline Construct/Items & Author (s) \\
\hline 3D Information quality (INF1-INF4) & $\begin{array}{l}\text { Algharabat and Zamil (2013); } \\
\text { DeLone and McLean (1992, } \\
\text { INFO1: 3D provides accurate information about the laptops }\end{array}$ \\
\cline { 1 - 1 } INFO2: 3D provides relevant information about the laptops & \\
\hline INFO3: 3D provides complete information about laptops & Algharabat and Zamil (2013); \\
\hline INFO4: 3D provides precise information about laptops & 3D System quality (SQ1-SQ4)
\end{tabular}




\begin{tabular}{|c|c|}
\hline $\begin{array}{l}\text { SQ1: The 3D is easy to use } \\
\text { SQ2: The 3D is user friendly }\end{array}$ & \multirow[t]{3}{*}{$\begin{array}{l}\text { DeLone and McLean (1992; } \\
\text { 2003) }\end{array}$} \\
\hline SQ3: The 3D is well designed to navigate & \\
\hline SQ4: The 3D is convenient to access & \\
\hline 3D Authenticity (AUTH1-AUTH4) & \multirow{5}{*}{ Algharabat and Dennis (2010) } \\
\hline $\begin{array}{l}\text { AUTH1: The } 3 \mathrm{D} \text { presentation is helpful for me to understand } \\
\text { the quality of the product }\end{array}$ & \\
\hline $\begin{array}{l}\text { AUTH2:The 3D lets me feel like I am holding a real laptop } \\
\text { and rotating }\end{array}$ & \\
\hline $\begin{array}{l}\text { AUTH3:The 3D lets me feel like I am dealing with a salesman } \\
\text { who is responding to my orders. }\end{array}$ & \\
\hline AUTH4:3D let me see the laptop as if it was a real one. & \\
\hline Enjoyment (ENJ1- ENJ4) & \multirow{5}{*}{$\begin{array}{l}\text { Koufaris (2002); Ghani } \\
\text { andDeshpande (1994) }\end{array}$} \\
\hline ENJ1: I find my experience with this website interesting. & \\
\hline ENJ2: I find my experience with this website enjoyable & \\
\hline ENJ3: I found my visit to this website entertaining & \\
\hline ENJ4: I found my visit to this website pleasant & \\
\hline Satisfaction (SAT1-SAT3) & \multirow{4}{*}{$\begin{array}{l}\text { Algharabat and Zamil (2013); } \\
\text { McKinney et al.(2002); } \\
\text { Wixomand Todd (2005) }\end{array}$} \\
\hline $\begin{array}{l}\text { SAT1: All things considered, I am very satisfied with } 3 \mathrm{D} \\
\text { product presentation }\end{array}$ & \\
\hline $\begin{array}{l}\text { SAT2: All things considered, I am very pleased with } 3 \mathrm{D} \\
\text { product presentation }\end{array}$ & \\
\hline $\begin{array}{l}\text { SAT3: My interaction with } 3 \mathrm{D} \text { product presentation has been } \\
\text { satisfying }\end{array}$ & \\
\hline Attitude toward website (ATTW1-ATTW3) & \multirow{4}{*}{$\begin{array}{l}\text { Almendros and Garcia (2015); } \\
\text { Castaneda et al. (2009) }\end{array}$} \\
\hline ATTW1: Good/Bad & \\
\hline ATTW2: Unfavorable/Favorable & \\
\hline ATTW3: Negative/Positive & \\
\hline Attitude toward presented product (ATPP1-ATPP3) & \multirow{4}{*}{$\begin{array}{l}\text { Van der Heijden et al. (2001); } \\
\text { Coyle and Thorson(2001); } \\
\text { Grazioli and Jarvenpaa (2000) }\end{array}$} \\
\hline $\begin{array}{l}\text { ATPP1: I would have positive feelings towards buying a } \\
\text { product from this site }\end{array}$ & \\
\hline $\begin{array}{l}\text { ATPP2: The thought of buying a product from this website is } \\
\text { appealing to me }\end{array}$ & \\
\hline $\begin{array}{l}\text { ATPP3: It would be a good idea to buy a product from this } \\
\text { website }\end{array}$ & \\
\hline Virtual Product Experience (VPE1-VPE4) & Algharabat (2014a) \\
\hline
\end{tabular}


VPE1: The 3D presentation is helpful for me to evaluate the product

VPE2: The 3D presentation is helpful for me to understand the performance of the product

VPE3: Evaluating the product on this website is compatible with how I evaluate products in physical stores

VPE4: Evaluating the product on this website fits well with the way Ilike to evaluate products in physical stores

\section{Results}

By using three statistical tools; SPSS 17, Smart PLS and AMOS 17, the proposed constructs and their measurement items were tested to validate the conceptual model and to examine the research hypotheses. Accurately, we used a combination of SPSS 17, SmartPLS, and AMOS 17; all variables were subjected to the univariate Skewness and Kurtosis tests and were noticed to be within their recommended levels.

\section{Normality}

Researchers employed skewness and kurtosis approachmethod to attain adequate level of normal distribution for the data collected in the current study and preventing a violation problems as well (Byrne, 2010; Hair et al., 2010; Kline, 2005; Tabachnick and Fidell, 2001). By returning to the AMOS21 output file, all variables were found to have an acceptable value of skewness and kurtosis. For instance, values of skewness were noticed all to be less than 3 point, which is acceptable as recommended by Kline (2005) and West et al. (1995). As for kurtosis, all values in this regard were also noticed within their recommended level by less than 8 .

\section{Measurement Models}

Both reliability and exploratory factor analysis were conducted so as to verify the structure and dimensionality of the proposed constructs.All constructs items were able to have a loading above 0.4 as well as statistical results approved that there is no overlapping between these items. 
In the first stage of the structural equation modelling analyses, measurement model was tested using AMOS 17.0. Thefocal construct of 3D-Q was considered as a second-order construct where INFO, SQ, AUTH, and ENJ all were treated as its first-order factors measures using their respective indicators. The initial results of the measurement model indicted that the model does not fit well as some of the fit indices (i.e. Goodness-of-fit index $[\mathrm{GFI}]=0.751$ and root mean square error of approximation [RMSEA] $=0.095$ ) were not found to be within their recommended level (Hair et al., 2006). Therefore, the measurement model was highly requested to be revised and purified. According to Byrne (2010); Hair et al.(2006); and Holmes-Smith et al. (2006), a number of criteria were adopted to improve the model fitness such of that researchers had a closer look at standardised regression weights (factor loading), modification indices, and standardised covariance matrix. Accordingly, researchers were able to identify the most problematic items (11 items) and the decision was made to remove all of these 11 items. Then, the revised version of the measurement model was tested again and as presented in Figure 2 and Table 3, all fit indices yielded in this time (i.e. $\chi^{2}=185.508, \mathrm{df}=98$, and $\chi^{2} / \mathrm{df}=1.893$; comparative fit index $[\mathrm{CFI}]=0.950$, goodness-of-fit index $[\mathrm{GFI}]=0.948$, Tucker-Lewis index $[\mathrm{TLI}]=0.952$, incremental fit index $[\mathrm{IFI}]=0.961$, and root mean square error of approximation $[$ RMSEA $]=0.047)$ were found to have values within their threshold level. Thus, supporting the model fitness for the measurement model of the second-order factor, therefore, the set of fit indices reported is consistent with $\mathrm{Hu}$ and Bentler's (1999) recommendations. The path coefficients between the indicators and their respective first-order factors were significant at $\alpha=0.05$ level.

In addition, as seen in Figure 3, with a value less than $\alpha=0.05$, INFO, SQ, AUTH, and ENJ all have a significant path with 3D-Q. The analysis supports the operationalisation of 3D-quality as a second-order factor consisting of its four factors (INFO, SQ, AUTH, and ENJ). Besides, as seen in Table 2, all factors were able to have adequate average variance extracted (AVE) value (higher than 0.60) as well as composite reliability (CR) value (higher than 0.70 ). Thus, both $\mathrm{CR}$ and AVE for all constructs matching their recommended standards (Fornell and 
Larcker, 1981; Kandemir, Yaprak and Cavusgil, 2006). This is in addition to the fact that all factors have an alpha coefficient value above 0.70 as suggested by Nunnally (1978).

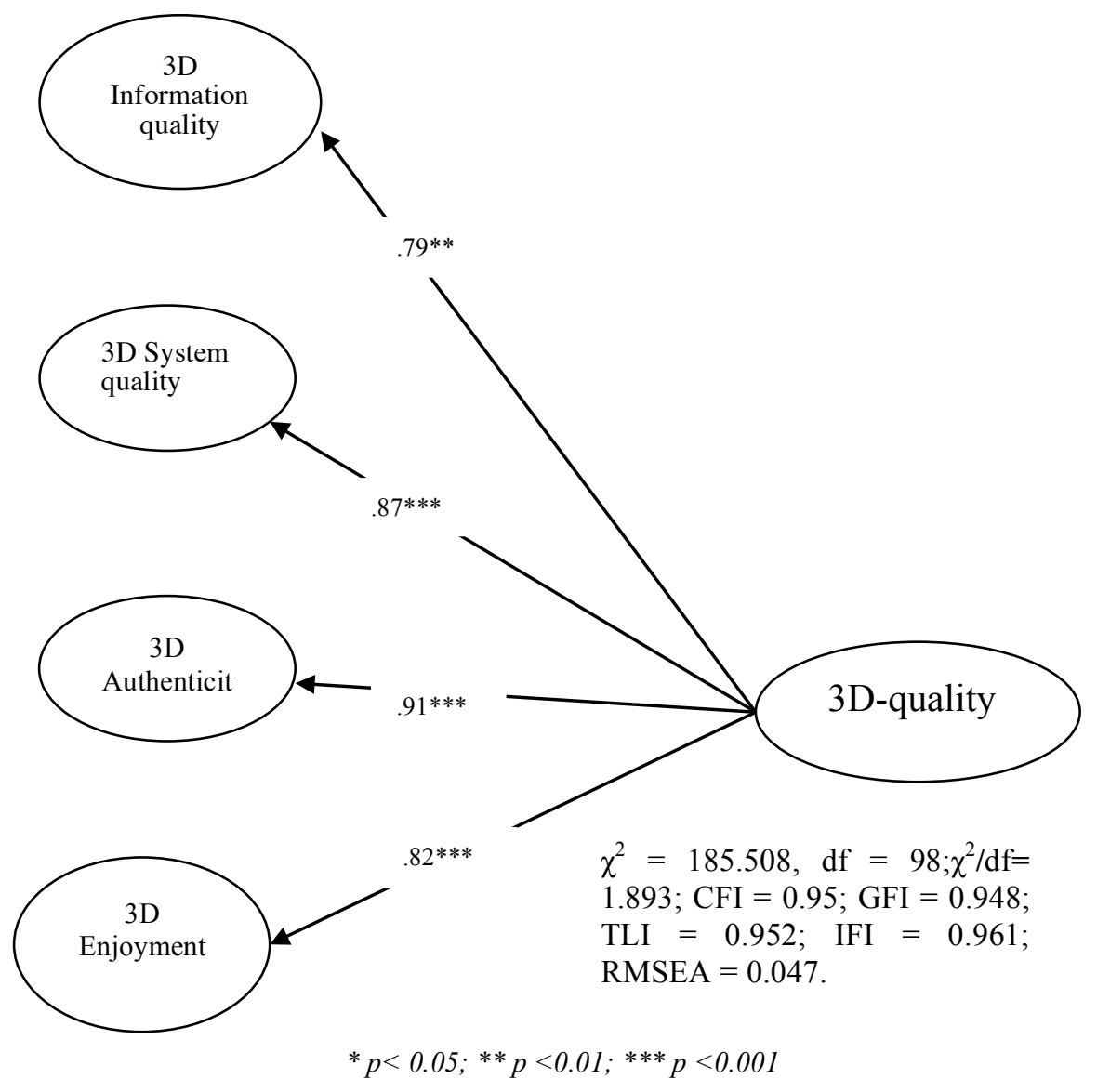

Figure 3. Second-order Factor analysis of 3D-Quality dimensions

Furthermore, the values of AVE for all constructs were found to be higher thanthe squared correlation coefficients for the corresponding constructs which supports the discriminate validity(Anderson and Gerbing 1988; Voss, Spangenberg and Grohmann, 2003).

Table 2.CFA: Using a Second-Order Conceptualisation of 3D-Quality

\begin{tabular}{|c|c|c|c|c|c|c|c|c|c|}
\hline Indicator & Direction & $\begin{array}{c}\text { Constr } \\
\text { uct }\end{array}$ & $\begin{array}{c}\text { Standardise } \\
\text { d } \\
\text { Loading }\end{array}$ & SE & t-value & $\mathrm{P}$ & CR & $\begin{array}{c}\text { AVE } \\
\%\end{array}$ & MSV \\
\hline INFO1 & $\leftarrow$ & INFO & 0.92 & & & & \multirow{3}{*}{0.94} & \multirow{3}{*}{78.4} & \multirow[t]{3}{*}{0.145} \\
\hline INFO2 & $\leftarrow$ & INFO & 0.84 & 0.043 & 12.547 & $* * *$ & & & \\
\hline INFO3 & $\leftarrow$ & INFO & 0.88 & 0.067 & 11.984 & $* * *$ & & & \\
\hline
\end{tabular}




\begin{tabular}{|c|c|c|c|c|c|c|c|c|c|}
\hline INFO4 & $\leftarrow$ & INFO & 0.90 & 0.031 & 15.275 & $* * *$ & & & \\
\hline SYS1 & $\leftarrow$ & SYS & 0.88 & & & & \multirow{4}{*}{0.94} & \multirow{4}{*}{81.09} & \multirow[t]{4}{*}{0.560} \\
\hline SYS2 & $\leftarrow$ & SYS & 0.89 & 0.078 & 13.240 & $* * *$ & & & \\
\hline SYS3 & $\leftarrow$ & SYS & 0.95 & 0.053 & 16.034 & $* * *$ & & & \\
\hline SYS4 & $\leftarrow$ & SYS & 0.88 & 0.052 & 12.350 & $* * *$ & & & \\
\hline AUTH1 & $\leftarrow$ & AUTH & 0.90 & & & & \multirow{4}{*}{0.95} & \multirow{4}{*}{83.32} & \multirow[t]{4}{*}{0.56} \\
\hline AUTH2 & $\leftarrow$ & AUTH & 0.89 & 0.079 & 14.311 & $* * *$ & & & \\
\hline AUTH3 & $\leftarrow$ & AUTH & 0.95 & 0.033 & 16.248 & $* * *$ & & & \\
\hline AUTH4 & $\leftarrow$ & AUTH & 0.91 & 0.082 & 14.321 & $* * *$ & & & \\
\hline ENJ1 & $\leftarrow$ & ENJ & 0.88 & & & & \multirow{3}{*}{0.91} & \multirow{3}{*}{77.45} & \multirow[t]{3}{*}{0.493} \\
\hline ENJ2 & $\leftarrow$ & ENJ & 0.87 & 0.101 & 10.316 & $* * *$ & & & \\
\hline ENJ3 & $\leftarrow$ & ENJ & 0.89 & 0.121 & 10.814 & $* * *$ & & & \\
\hline
\end{tabular}

Notes: The respective items for INFO, SYS, AUTH, and ENJ are numbered serially

Table 3 presents the correlation between the four different variables and also establishes the discriminant validity on this basis.

Table 3. Discriminant Validity of 3D-quality

\begin{tabular}{|l|c|c|c|c|}
\hline Variable & INFO & SYS & AUTH & ENJ \\
\hline INFO & $\mathbf{0 . 8 9}$ & & & \\
\hline SYS & 0.30 & $\mathbf{0 . 9 0}$ & & \\
\hline AUTH & 0.25 & 0.26 & $\mathbf{0 . 9 1}$ & \\
\hline ENJ & 0.23 & 0.34 & 0.15 & $\mathbf{0 . 8 8}$ \\
\hline
\end{tabular}

Note. The numbers in diagonal line are the average variance extracted by each construct. The numbers above the diagonal show the squared correlation coefficients between the constructs

CFA (on all five latent factors: 3D-Q, ATPP, and ATTW, SAT and VPE) model fit deemed to be acceptable on the basis of a set of fit indices $\left(\chi^{2}=535.452, \mathrm{df}=\right.$ 314 ; and $\left.\chi^{2} / \mathrm{df}=1.705\right)$,comparative fit index $[\mathrm{CFI}]=0.942$, goodness-of-fit index $[\mathrm{GFI}]=0.921$, Tucker-Lewis index $[\mathrm{TLI}]=0.934$, incremental fit index $[\mathrm{IFI}]=$ 0.952 , and root mean square error of approximation $[$ RMSEA] $=0.042$ ) consistent with $\mathrm{Hu}$ and Bentler's (1999) recommendations. Furthermore, Table 4 shows standard error (SE), t-value, composite reliabilities, AVE and MSV. 
Table 4. Results of the CFA within the Five Latent Factors

\begin{tabular}{|c|c|c|c|c|c|c|c|c|c|}
\hline Indicator & Direction & Construct & $\begin{array}{c}\text { Standardised } \\
\text { Estimate }\end{array}$ & SE & $\begin{array}{c}\text { t- } \\
\text { value }\end{array}$ & $\mathrm{P}$ & CR & AVE & MSV \\
\hline 3D-Q1 & $\leftarrow$ & $3 \mathrm{D}-\mathrm{Q}$ & 0.78 & & & & \multirow{4}{*}{0.91} & \multirow{4}{*}{72.04} & \multirow[t]{4}{*}{0.666} \\
\hline 3D-Q2 & $\leftarrow$ & $3 \mathrm{D}-\mathrm{Q}$ & 0.87 & 0.069 & 12.607 & $* * *$ & & & \\
\hline 3D-Q3 & $\leftarrow$ & $3 \mathrm{D}-\mathrm{Q}$ & 0.91 & 0.069 & 13.386 & $* * *$ & & & \\
\hline 3D-Q4 & $\leftarrow$ & $3 \mathrm{D}-\mathrm{Q}$ & 0.82 & 0.062 & 11.106 & $* * *$ & & & \\
\hline ATPP1 & $\leftarrow$ & ATPP & 0.94 & & & & \multirow{3}{*}{0.92} & \multirow{3}{*}{75.06} & \multirow[t]{3}{*}{0.246} \\
\hline ATPP2 & $\leftarrow$ & ATPP & 0.84 & 0.071 & 11.412 & $* * *$ & & & \\
\hline ATPP3 & $\leftarrow$ & ATPP & 0.87 & 0.075 & 11.425 & $* * *$ & & & \\
\hline ATTW1 & $\leftarrow$ & ATTW & 0.80 & & & & \multirow{3}{*}{0.90} & \multirow{3}{*}{68.16} & \multirow[t]{3}{*}{0.424} \\
\hline ATTW2 & $\leftarrow$ & ATTW & 0.81 & 0.074 & 7.914 & $* * *$ & & & \\
\hline ATTW3 & $\leftarrow$ & ATTW & 0.88 & 0.067 & 8.767 & $* * *$ & & & \\
\hline SAT1 & $\leftarrow$ & SAT & 0.92 & & & & \multirow{3}{*}{0.91} & \multirow{3}{*}{76.44} & \multirow[t]{3}{*}{0.569} \\
\hline SAT2 & $\leftarrow$ & SAT & 0.89 & 0.096 & 13.657 & $* * *$ & & & \\
\hline SAT3 & $\leftarrow$ & SAT & 0.88 & 0.090 & 11.927 & $* * *$ & & & \\
\hline VPE1 & $\leftarrow$ & VPE & 0.85 & 0.054 & & & \multirow{4}{*}{0.94} & \multirow{4}{*}{79.82} & \multirow[t]{4}{*}{0.666} \\
\hline VPE2 & $\leftarrow$ & VPE & 0.87 & 0.071 & 10.235 & $* * *$ & & & \\
\hline VPE3 & $\leftarrow$ & VPE & 0.91 & 0.76 & 8.262 & $* * *$ & & & \\
\hline VPE4 & $\leftarrow$ & VPE & 0.94 & 0.65 & 12.230 & $* * *$ & & & \\
\hline
\end{tabular}

Table 5 shows discriminant validity through Pearson correlation between constructs against the square roots of AVE across diagonal, which all improved to be acceptable.

Table 5. Internal Consistency and Discriminant Validity of Constructs

\begin{tabular}{|l|c|c|c|c|c|}
\hline Construct & 1 & 2 & 3 & 4 & 5 \\
\hline 1. 3D-Quality & $\mathbf{0 . 8 5}$ & & & & \\
\hline 2. ATTW & 0.25 & $\mathbf{0 . 8 7}$ & & & \\
\hline 3. ATPP & 0.15 & 0.38 & $\mathbf{0 . 7 8}$ & & \\
\hline 4. SAT & 0.30 & 0.42 & 0.20 & $\mathbf{0 . 8 7}$ & \\
\hline 5. VPE & 0.14 & 0.25 & 0.17 & 0.41 & $\mathbf{0 . 8 9}$ \\
\hline
\end{tabular}

Note: The figures under the diagonal are the Pearson (R) correlations between the variables. Diagonal elements are square roots of average variance extracted. 


\section{Common Method Bias}

So as to avoid any concern regarding common method bias as the current study data is self-reported (Bhattacherjee, 2012; Podsakoff et al., 2003), researchers employed Harman's single-factor (Harman, 1976). Harman's single-factor test is highly adopted and recommended to examine common method bias as reported by Malhotra et al. (2006) and Podsakoff et al. (2003). Therefore, the removable items of eight constructs (system quality, information quality, authenticity, enjoyment, attitude toward product presentation, attitude toward website, users' satisfaction and VPE) were subjected to the Harman's single-factor. All of the subjected items have been loaded to exploratory factor analysis and an unrotated factor solution was employed for this purpose. According to the main empirical; findings extracted, emerging single factor did not exist in addition to the fact that 44.355 percent of variance was accounted by the first factor. This value is not more than 50 percent as highly recommended in the study of Podsakoff et al., (2003). Therefore, it could clearly assure that the current study data is free of any problems regarding the common method bias.

\section{The Structural Model}

To test the structural model, we followed up three stages (see Table 6). Stage one tests Model 1, which represents the conceptual framework without the moderating variable (VPE). Model 2 represents the conceptual framework including the moderating variable. Model 3 is the full model that includes the interaction effectof attitude toward presented product and virtual product experience on user satisfaction as well as the interaction effect of attitude toward website and VPE on user satisfaction. We employed a bootstrapping method (500 times) that used randomly selected subsamples to test the PLSmodel. Using this method improves the assessment of (non)-direct effects, the comparison of effects, and the evaluation of the coefficient of determination (Streukens and Leroi-Werelds, 2016).

Model 1 fit measures indicated acceptable agreement with the covariance in the data $\left(\chi^{2}=541.856, \mathrm{df}=267, \chi^{2} / \mathrm{df}=2.029 ; \mathrm{CFI}=0.92 ; \mathrm{GFI}=0.91 ; \mathrm{AGFI}=0.90 ;\right.$ 
TLI $=0.92 ;$ IFI $=0.90 ;$ and RMSEA $=0.049)$. The results of the hypothesis testing support all postulated paths for $\mathrm{H} 1-\mathrm{H} 4$. We found that $3 \mathrm{D}-\mathrm{Q}$ was positively associated with ATPP $(\beta=0.59, p<0.001)$ and ATTW $(\beta=0.69, p$ $<0.001)$. Furthermore, we found that ATTP positively impacts satisfaction $(\beta=$ $0.40, p<0.001)$ and ATTW positively impacts satisfaction $(\beta=0.25, p<0.001)$.

Model 2 fit measures indicated acceptable agreement with the covariance in the data $\left(\chi^{2}=963.952 ; \mathrm{df}=368 ; \chi^{2} / \mathrm{df}=2.619 ; \mathrm{CFI}=0.90 ; \mathrm{GFI}=0.91 ; \mathrm{AGFI}=0.90\right.$; TLI $=0.91 ;$ IFI $=0.90 ;$ and RMSEA $=0.054)$. The results of the hypothesis testing support all postulated paths for $\mathrm{H} 1-\mathrm{H} 4$. We found that $3 \mathrm{D}-\mathrm{Q}$ was positively associated with ATPP $(\beta=0.58, p<0.001)$ and ATTW $(\beta=0.67, p$ $<0.001)$. We found that ATPP positively impact user'ssatisfaction $(\beta=0.32, p$ $<0.001)$ and ATTW positively impact user'ssatisfaction $(\beta=0.39, p<0.001)$. Furthermore, we find that VPE has no significant impact on satisfaction $(\beta=$ $0.04)$.

To test Model 3, we used Partial Least Squares (PLS) with SmartPLS software program (this combined method of using AMOS and PLS has been used by Yoon et al. (2013). We followed Chin et al.'s (2003) suggestion to test for the interaction effects using PLS. Results confirm that VPE moderating H4a and H4b.

Table 6. Results for the structural models

\begin{tabular}{|l|c|c|c|}
\hline Construct & Model 1 & Model 2 & Model 3 \\
\hline Direct effect & & & \\
3D-Q $\rightarrow$ ATTP & $0.59 * * *$ & $0.58^{* * *}$ & $0.54 * * *$ \\
3D-Q $\rightarrow$ ATTW & $0.69 * * *$ & $0.67 * * *$ & $0.67 * * *$ \\
ATTP $\rightarrow$ SAT & $0.40^{* * *}$ & $0.32^{* * *}$ & $0.34 * * *$ \\
ATTW $\rightarrow$ SAT & $0.25^{* * *}$ & $0.39 * * *$ & $0.38^{* * *}$ \\
VPE $\rightarrow$ SAT & & 0.04 & 0.02 \\
\hline Interaction effect & & & \\
VPE $\star$ ATTP $\rightarrow$ SAT & & & $0.10 *$ \\
VPE $\star$ ATTW $\rightarrow$ SAT & & & $0.15 *$ \\
\hline R & & & \\
ATTP & 0.30 & 0.33 & 0.35 \\
ATTW & 0.48 & 0.45 & 0.48 \\
SAT & 0.47 & 0.48 & 0.48 \\
\hline
\end{tabular}




\section{Discussion}

This study investigates the impact of 3D product presentation quality on attitude toward presented product and attitude toward website which in turn impact users' satisfaction. Furthermore, we investigated the role of VPE as a moderator between attitude and user'ssatisfaction. Based on the fact that previous research treated 3D-Q as a unidimensional construct (Algharabat and Shatnawi, 2014; Algharabat and Zamil, 2013), and in order to conceptualise and to define 3D-Q, we established a combined scale (second-order) treating the 3D-Q construct as a multi-dimensional one. Our results supported the combined scale and therefore we believe that $3 \mathrm{D}-\mathrm{Q}$ is a multi-dimensional construct and therefore the using of the current combined scale should reflect the main dimensions for the 3D-Q.

Therefore, 3D-Q scale should reflect information quality, system quality, authenticity constructs. We expect that 3D-Q dimensions will enhance customers' ability to evaluate the quality of the presented product and it increases users' ability to learn more about the product. To that end, enjoyment is considered an important dimension in measuring 3D-Q, since this dimension focuses more on the enjoyment part of the 3D-Q, and we believe that many users might come to visit a website which has a 3D product presentation for the sake of fun.Ourresults express that the combined 3D-Q scale possesses strong psychometric properties, suggesting that information quality, system quality, authenticityand enjoyment constitute four independent yet correlated dimensions of the 3D-Q construct.

Therefore, it could be noticed from the second-order analysis (Figure 3) of 3D-Q dimensions that authenticity has the strongest impact on creating $3 \mathrm{D}$ quality. Algharabat and Dennis (2010) assert the importance of this construct to reflect real simulation of the offline products.Furthermore, it is highly significant for online retailers who intended to invest on the 3D technology to focus on designing the proper $3 \mathrm{D}$ product presentation to be perceived as actual objects. In other words, authenticity of the 3D product presentation enhances users' perceptions of its quality.Therefore, authenticity of 3D product presentation increases 3D-Q. Furthermore, this result is supported by Algharabat's (2014a) study which 
identified authenticity as a main dimension of VPE. The author asserts that the quality of $3 \mathrm{D}$ product presentation is restricted to its authenticity.

We find (see Figure 3) that system quality is the second important dimension for creating 3D-Q. Therefore, the 3D product presentation should be designed to reflect users' ability to easily zoom in or out on the 3D product presentation, their ability to rotate it and control the form and content of it. This dimension will enhance users' perceptions of the 3D quality. This result has been confirmed within previous 3D-Q literature. For example, Algharabat and Zamil (2013) measured 3D-Q using 3D system quality. The authors posit that easy to use, user friendly, and navigation are the main attribute which a 3D product presentation should have to reflect 3D system quality. Moreover, this result comes in accordance with Algharabat and Shatnawi (2014) results which assert that ease of use is a main determinant for $3 \mathrm{D}-\mathrm{Q}$.

We find that enjoyment (see Figure 3) counts for the third important dimension which impact 3D-Q.Therefore, the 3D product presentation should be designed to enhance users' ability to feel the enjoyment which comes from manipulatingthe $3 \mathrm{D}$ product presentation (i.e., its colours and zoom in or out)and thus enhances their enjoyment.This result comes in accordance with Algharabat and Shatnawi (2014) results which identifiedperceivedenjoymentas a main determinant for 3DQ. This result also comes in line with Algharabat's (2014a) study which identified enjoyment quality as a main dimension of VPE.

We find (see Figure 3) that information quality is the least important dimension for creating 3D-Q. Therefore, the 3D product presentation should be designedto introduce different, relevant, sufficient and accurateinformation about the presented product.This result has been confirmed within previous 3D-Q literature. For example, Algharabat and Zamil (2013) measured 3D-Q using 3D information quality. The authors posit that information quality reflects information relevancy, sufficiency, accuracy and currency which are the main attribute of 3D information quality. Moreover, this result comes in accordance with Algharabat and Shatnawi (2014) results whish assert that ease of use is a main determinant for 3D-Q. 
The results of this research supported the hypotheses (H1a and H1b) that 3D-Q has a significant impact onusers' attitudes toward the presented product and users' attitude toward the website which utilize the 3D technology (Model 1). According to the path coefficient analyses, we find that $3 \mathrm{D}-\mathrm{Q}$ was proven to be the most significant factor predicting attitude toward website with acoefficient value of 0.69 with $\mathrm{R}^{2}$-value of $0.48 .48 \%$ of attitude toward website total varianceis explained by 3D-Q. That means users' how to find a highquality 3D product presentation often formulate a positive attitude toward the online retailerwebsite. This could be attributed to the ability of a 3D product presentation with its different dimensions (authenticity, system quality, information quality and entertainment) to reflect a high quality of the 3D which in turn impacts users' attitude toward online retailer website. Therefore, online retailers who design the 3D-Q properly to reflect its dimensions are expected to enhance users' attitude toward the website. This result comes in accordance with previous studies, which assert the importance of ease of use and usefulness on users' attitude (Davis, 1989). Coyle and Thorsen (2001) found that high level of vividness resulted in stronger attitudes toward website.

Another result shows that the relationship between 3D-Q and attitude toward the presented product comes as second important path coefficient. We find that attitude towardpresented product with acoefficient value of 0.59 and $\mathrm{R}^{2}$ of 0.30 in Model $1.30 \%$ of attitude toward presented product total varianceis explained by 3D-Q.That means users how to find a high quality 3D product presentation often formulate a positive attitude toward the presented product. This could be attributed to the ability of a 3D product presentation with its different dimensions (authenticity, system quality, information quality and entertainment) to reflect a high quality of the 3D which in turn impact users' attitude toward the presented product. This result is supported by previous findings (Algharabat and Zamil, 2013; Li et al., 2002, 2003; Klein, 2003; Fiore and Jin, 2003; Suh and Lee, 2005), which posit the positive relationship between $3 \mathrm{D}$ product presentation and attitude toward product. 
Our results show that attitude toward website and attitude toward the presented product are significantly impacting users' satisfaction.According to the path coefficient analyses; we find that attitude toward presented product is proven to be the most significant factor predicting users'satisfaction with acoefficient value of 0.40 , followed by attitude toward website, which counts for 0.25 , with $\mathrm{R}^{2}$ of 0.47. That means users who have positive overall evaluation (cognitive and affective) of the presented 3D product tend to be satisfied. On the other hand, users who have positive attitude toward the website also have the feelings of being satisfied. This result comes in accordance with previous research on $3 \mathrm{D}$ field (Algharabat and Zamil, 2013). The above results show that a well-designed $3 \mathrm{D}$ presentation not only creates positive attitude toward the website but also toward the product which end up with users' satisfaction. Therefore, online retailers should aim to build users attitude, which is expected to lead to users' satisfaction. Therefore, our results confirm the positive relationships between attitude toward presented product and users' satisfaction (H2), and attitude toward the website and users' satisfaction (H3).

This paper explores themoderating effect of virtual product experience on the relationship of attitude toward presented product and user's satisfaction, and attitude toward the website and user's satisfaction. The findings indicate that VPE moderates the relationship of attitude toward presented product with satisfaction (H4), as well as, the relationship of attitude toward website with satisfaction (H5). The full model (see Model 3), which discusses the interaction effect of the moderator shows that satisfaction, the dependent construct, has $\mathrm{R}^{2}$ value of 0.48 indicating that the model accounts for $48 \%$ of the variancein the dependent construct. The inclusion of the interaction terms between attitude toward website and user's satisfaction raises the $\mathrm{R}^{2}$ value of satisfaction variance to 0.48 in Model 3. While $\mathrm{R}^{2}$ value for attitude toward the presented product increased to 0.35 in Model 3. These $\mathrm{R}^{2}$ values for the path coefficients are all significantat the 0.05 level or below.

According to Baron and Kenny (1986) a moderator is a variable that affects the strength or direction of a relationship between an independent construct and a 
dependent construct. First, the impact of VPE on the strength of the relationship between attitude toward website and users' satisfaction (the slight increase of $\mathrm{R}^{2}$ from 0.47 to 0.48 ) and between attitude toward presented product and users' satisfaction (slight increase of $\mathrm{R}^{2}$ from 0.30 to 0.35 ) can be seen by examining the explained variance and does show strong influence of the moderator on the strength of the relationship. Therefore, the slight increase does not show strong influence of the moderator on the strength of the relationships.

Second, moderation of the direction of the relationship is detected by looking at the interaction effects. The significant regression coefficient for the interaction terms (with path coefficient 0.15 and is significant at 0.05 level) indicates that VPE positively impacts the relationship between attitude toward website and users' satisfaction. Similarly, the significant regression coefficient or the interaction terms $(0.10)$ does support the positive direction of the relationship between attitude toward the product and users' satisfaction by the moderator.

The above results show that VPE is shown to positively moderate the relationship between attitude toward website and users' satisfaction as well as attitude toward presented product and users' satisfaction. Thus, with the increasing level of VPE, it becomes more influential towards generating users' satisfaction with the online retailer.

\section{Implications for Theory}

To the best of the authors' knowledge, the findings of the current study advance the existing research on 3D-Q by making the following important contributions to the research literature. First, unlike previous studies on 3D-Q, the current research integrated the main elements, which enhance the quality of $3 \mathrm{D}$ product presentation, in a mediated computer environment, to measure 3D-Q. Furthermore, we focused on 3D information system to reflect the ability of the 3D interface to measure functional tools, which often reflected by the interactivity and vividness tools of the $3 \mathrm{D}$ interface to communicate information properly to consumers. 3D system quality used in this context to reflect ease of use, user friendly, and well designed to navigate the presented product. Furthermore, we 
employed the notion of authenticity to reflect the ability of the $3 \mathrm{D}$ product interface to communicate a real product which consumers can find both online and offline. To that end, our findings, also, indicate the importance of enjoyment as a main dimension which enhances consumers' perceptions of the quality of the $3 \mathrm{D}$ interface. The above dimensions of 3D-Q have been derived from the existing literature which has not combined them together and thus, our results indicate their importance. We believe that our suggested scale reflects many important dimensions which previous scholars did not explain the way we did. For example, previous research (Li et al., 2001, 2002, 2003) on VPE posits the importance of telepresence to measure the quality of the $3 \mathrm{D}$ product presentation. However, to do so some researchers focused on manipulating the level of interactivity measured by user control (Klein, 2003), others (Hopkins et al., 2004) focused on manipulating levels of vividness, measured by media richness but not interactivity, to measure telepresence. Furthermore, other researchers cantered their efforts toward measuring the quality of the $3 \mathrm{D}$ interface via notions such as functional mechanisms (Jiang and Benbasat 2007a) measured via vividness and interactivity and they ignored the notion of telepresence. Others (Jiang and Benbasat, 2005) focused on the notion of virtual control (measured with both virtual control and functional control). To that end we believe that our combined scale dimensions focused on interactivity tools, which illustrated by $\mathrm{Xu}$ and Sundar (2014), and vividness tools, which explained by Jiang and Benbasat (2007a). Thus, we believe that 3D information quality has the ability to communicate, verbally and non-verbally, the proper information regarding the $3 \mathrm{D}$ interface to consumers. Moreover, 3D system quality is another important dimension for the 3D interface which previous research has not discussed. Therefore, we employed this construct and adapted Algharabat and Zamil (2013) and DeLone and McLean's (1992, 2003) scales to measure it. Therefore, we believe that previous studies neither tested our scale nor introduced such a combined scale to measure 3D-Q. Therefore, this study introduced a new measurement scale for 3D-Q. 
Second, another contribution of the current study to the literature is building an empirical connection between the impact of 3D-Q on users' attitude toward presented product and their attitude toward the website, which have not empirically tested. Third, previous research has not tested VPE (as a continuous construct) as a moderator within the context of online retailers. Fourth, this study tested the impact of 3D-Q on users'attitude toward presented product and attitude toward the website. Fifth, we have introduced new factors such as 3D-Q, and VPE, which have been examined within new context. Sixth, new relationships have been examined within the context of non-western one. Seventh, we provided a contribution to the IS and marketing fields by combining different theories. Finally, the design of this research considered another contribution, the way which we designed the $3 \mathrm{D}$ interface enable us to test the relationships among the proposed constructs which was not possible in previous studies which attempt to measure the quality of 3D interface.

\section{Implications for Practice}

Results from this paper provide practitioners and marketing managers with information for deploying 3D-Q dimensions on online retailers' websites, and their implementations. The dimensions of 3D-Q shed a light on the main aspects which online retailers should focus on. Therefore, online retailers who are using 3D product presentation should increase users' knowledge and experience by focusing on developing and designing the 3D interface to reflect; (i) genuine authentic simulation of the offline product, (ii) system quality in which the $3 \mathrm{D}$ interface should achieve ease of use, user friendly, and design attribute, (iii) the 3D interface should reflect a high level of enjoyment, and (iii) the information about the 3D product should be designed to introduce different, relevant, sufficient and accurate information about the presented product. Thus, this study informs e-retailers of the importance of the above dimensions on creating 3D-Q. Therefore, this study suggests that e-retailers put efforts into designing and developing the above dimensions to reflect high quality of $3 \mathrm{D}$ product presentation. 
Online retailers using 3D product presentation should focus on the importance of having 3D interface, which is usable and provide users with the needed information about the product. Furthermore, designing the 3D interface should reflect its authenticity and it should provide users with certain level of enjoyment via the rotation, zoom in or out and changing the colour of the presented product. 3D-Q often enhances the e-shopping environment (Khakimdjanova and Park 2005; Park, Stoel and Lennon 2008).

The results of this study provide practitioners with more information on which to base their decisions for 3D-Q design and implementations in their e-commerce websites. For example, providing users with a high quality $3 \mathrm{D}$ interface leads to create positive relationships with attitude toward website as well as attitude toward the presented product provides users with positive evaluations for both the online retailers' website and the presented product which use 3D technology. Thus, it is expected that online retailers should focus on the main elements which impact developing users' attitude. This is expected to take a place as long as online retailers investigate the cognitive, affective and conative elements of their customers while they browse online. This can be achieved via understanding the needs and interests of individual users or user groups, and user shopping experience and interests. Furthermore, adding 3D-Q dimensions enhance users' overall experience.

The relationship between attitude toward website and user's satisfaction as well as the relationship between attitude toward the presented product and user's satisfaction give more insights for marketing managers. For example, users who have positive attitude (toward the web or/and toward the presented product) tend to be more satisfied about the website. Therefore, online retail managers should understand the main elements, which create user's satisfaction as a result of using novel stimulus. This satisfaction might differ from country to another. Thus, managers should continuously conduct customer satisfaction surveys in order to recommend new and novel designs for the $3 \mathrm{D}$ product presentation and increase user satisfaction with the websites. Online retailers who employ the 3D 
technology will gain a distinctive advantage, be better positioned to compete and, thus, assist consumers through the online shopping experience.

\section{Limitations and Future Research}

The following limitations of the current study should be kept in mind. First, the hypothetical online retailer, which we designed, focused solely on laptop industry. Second, this study only focused on the viewpoints of 410 sample size that uses online retailers in Jordan, Middle East. This means that the investigation of therelationship between 3D-Q, attitude toward the website, attitude toward presented product, anduser'ssatisfaction are only basedon the perspectives of Jordanian users. Thus, results may have been different from the perspective of various western context backgrounds.

Third, this study lacked sufficient empirical research to support the fact that VPE positively moderates the relationship between, attitude toward the website and user's satisfaction as well as attitude toward presented productand user's satisfaction. We recommend that researchers investigate the impact of $3 \mathrm{D}-\mathrm{Q}$ on trust and purchase intention with the existence of the VPE as a moderator.

\section{Conclusion}

This research aims to assess the moderating effect of VPE on the relationship between attitude toward website and user satisfaction as well as attitude toward presented product and user satisfaction. As expected, the results clearly confirmed the relationship between attitude toward website, attitude toward presented product and user satisfaction with the website which has $3 \mathrm{D}$ technology. Close to $48 \%$ of the variance in customer satisfactioncan be explained by attitude with the website and product as measuredhere. The results, second-order, show that effective 3D-Q has a significant impact enhancing attitude (toward website and product), which in turn directly affects customer satisfaction with the website. Further, virtual product experience is shown to positively moderate the relationship between attitude toward website and satisfaction with the website. Moreover, results found that virtual product experience positively moderates the 
relationship between attitude toward presented product and satisfaction with the website.

\section{References}

Alba, J.W., \& Hutchinson, J.W. (1987). Dimensions of consumer expertise. Journal of Consumer Research, 13, pp. 411-454.

Algharabat, R. (2016) The Role of 3D Product Presentation in Enhancing Virtual Experience Realms: The Case of consumer responses towards Online Apparel Retailers, in In Lee, Encyclopaedia of E-Commerce Development, Implementation, and Management, Volume III pp. 1724-1736, Category: Online Consumer Behavior, Western Illinois University, USA

Algharabat, R. (2014a). Conceptualising and modelling virtual product experience for online retailers.Int. J. Internet Marketing and Advertising, Vol. 8, No. 4, pp. 300-319.

Algharabat, R. (2014b) The role of 3D product presentation in enhancing electronic customer relationship management (e-CRM) for online retailer: university students context, Int. J. Electronic Customer Relationship Management, Vol. 8, No. 4, pp. 159-179

Algharabat, R. and Abu-ElSamen, A. (2013). Modelling the impact of 3D product presentation on online behaviour, Int. J. Electronic Marketing and Retailing, Vol. 5, No. 3, pp. 242-264

Algharabat, R. and Dennis, C. (2010) 'Using 3D product visualisation for an Electrical Online Retailer, Journal of Customer Behaviour, Vol. 9 No. 2, pp. 97-116

Algharabat, R. and Shatnawi, T. (2014) The Effect of 3D Product Quality (3D-Q) on Perceived Risk and Purchase Intentions: The Case of Apparel Online Retailers, Int. J. Electronic Business, Vol. 11, No. 3, pp. 262-279.

Algharabat, R. and Zamil, A. (2013) 'An empirical investigation of 3D-based information systems success for online retailers, Int. J. Technology Marketing, Vol.8, No. 3, pp. 316-336. 
Almendros, C., and Garcia, S. (2015) Expert vs. novice users: Comparative analysis of the effectiveness of online discounts and gifts, Revista Espanola de Investigacion de Marketing ESIC., 19, pp. 46-61.

Anderson, J. C. and Gerbing, D.W. (1988) 'Structural Equation Modeling in Practice: A Review and Recommended Two-Step Approach', Psychological Bulletin, Vol. 103, No. 3, pp. 411-423.

Ariely, D. (2000) 'Controlling the Information Flow: Effects on Consumers' Decision Making and Preferences', Journal of Consumer Research, 26, pp. 233-248.

Armstrong, J. S., and Overton, T. S. (1977) 'Estimating non-response bias in mail surveys', Journal of Marketing Research, Vol. XIV, pp. 396-402.

Baron, R.M. and Kenny, D.A. (1986) The moderator-mediator variable distinction in socialpsychological research: conceptual, strategic, and statistical considerations. Journal of Personality and Social Psychology, 51 (6), pp. 1173-1182.

Bhattacherjee, A. (2012). Social science research: Principles, methods, and practices. ( $2^{\text {nd }}$ Ed.). Florida, USA.

Bilgihan, A. (2016). Gen Y customer loyalty in online shopping: An integrated model of trust, user experience and branding. Computers in Human Behavior, 61, 103-113.

Bryman, A. and Bell, E. (2007).Business research methods. $\left(2^{\text {nd }}\right.$ Ed.), Oxford: Oxford University Press.

Castaneda, J. A., Rodriuez, M. A., \&Luque, T. (2009).Attitudes' hierarchy of effects in on-line user behavior.Online Information Review, 33(1), pp. 7-21.

Castillo, J. J. (2009). Population sampling techniques. Available at: https://explorable.com/ simple-random-sampling. Accessed: 30.03.13.

Chaiken, S. (1980). Heuristic versus systematic information processing and theuse of source versus message cues in persuasion. Journal of Personality and Social Psychology, 41, pp. 1-12. 
Chen, Y., Yan, X., Fan, W., and Gordon, M. (2015).The joint moderating role of trust propensity and gender on consumers' online shopping behavior.Computers in Human Behavior, 43, 272-283.

Chin, B.L. Marcolin, P.R. Newsted (2003) A partial least squares latent variable: Carlo simulation study and an electronic-mail emotion/adoption study, Information Systems Research 14, pp. 189-217.

Coyle, J.R. and Thorson, E. (2001) 'The effects of progressive levels of interactivity and vividnessin web marketing site', Journal of Advertising, Vol. 30, No. 3, pp.65-77.

Davis, F.D. (1989) 'Perceived usefulness, perceived-ease-of-use and user acceptance of information technology', MIS Quarterly, Vol. 13, No. 3, pp.319340.

DeLone, W.H. and McLean, E.R. (1992) 'Information system success: the quest for the dependentvariable', Information Systems Research, Vol. 3, No. 1, pp.60-95.

DeLone, W.H. and McLean, E.R. (2003) 'The DeLone and McLean model of information systemsuccess: a ten-year update', Journal of Management Information Systems, Vol. 19, No. 4,pp.9-30.

Dwivedi, Y. K., Choudrie, J., and Brinkman, W. P. (2006).Development of a survey instrument to examine consumer adoption of broadband.Industrial Management and Data Systems, 106(5), pp. 700-718.

Eisenmann, T. and Pothen, S.T. (2000) Online Portals, pp.1-29, Case Number 9801-305, HarvardBusiness School, Boston, MA

Fiore, A. and Jin, H-J. (2003) 'Influence of Image Interactivity on Approach Responses Towards an Online Retailer', Internet Research: Electronic Networking Applications and Policy, Vol. 13, No. 1, pp. 38-48.

Fiore, A., Kim, J, and Lee, H-H. (2005) 'Effects of Image Interactivity Technology on Consumer Responses Toward the Online Retailing', Journal of Interactivity Marketing, Vol. 19, No. 3, pp. 39-53.

Fishbein, M., Ajzen, I. (1975). Belief, Attitude, Intention, and Behavior: An Introduction to Theory and Research.Addison-Wesley, Reading, MA. 
Fornell, C., and Larcker, D. F. (1981) 'Evaluating structural equation models with unobservable variables and measurement error', Journal of Marketing Research, Vol. 18, pp. 39-50.

Gefen D, Karahanna E, Straub, DW. (2003) Inexperience and experience with online stores: the importance of TAM and Trust. IEE Trans EngManag 50, pp. $307-321$.

Ghani, J. A., and Deshpande, S. P. (1994).'Task characteristics and the experience of optimal flow in human-computer interaction', Journal of Psychology, Vol. 128 No. 4, pp. 381-391.

Grazioli, S., S. L. Jarvenpaa. (2000) 'Perils of Internet fraud: An empirical investigation of deception and trust with experienced Internet consumers', IEEE Trans. Systems, Man, Cybernetics Vol. 30, No. 4, pp. 395-410.

Hair, J., Anderson, R., Tatham, R., and Black, W. (1998), Multivariate Data Analysis, Prentice-Hall, Upper Saddle River, NJ

Hasan, B. (2016). Perceived irritation in online shopping: The impact of website design characteristics. Computers in Human Behavior, 54, 224-230.

Heijden, H. v. d., Verhagen, T., Creemers, M. (2003) 'Understanding online purchase intentions: Contributions from technology and trust perspectives', European Journal of Information Systems, Vol. 12, pp. 41-48.

Ho, L. A., Kuo, T. H., and Lin, B. (2012). The mediating effect of website quality on Internet searching behavior.Computers in Human Behavior, 28(3), 840-848.

Hoch, S.J., \& Deighton, J. (1989) 'Managing What Consumers Learn from Experience', Journal of Marketing, 53, pp. 1-20

Hoffman, D., and Novak, T. (1996) 'Marketing in hypermedia computer-mediated environments: Conceptual foundations', Journal of Marketing, Vol. 60, pp. 5068.

Hopkins, C D., Raymond, M A, and Mitra, A. (2004) 'Consumer Responses to Perceived Telepresence in the Online Advertising Environment: The Moderating Role of Involvement', Marketing Theory', Vol. 4 No. 137, pp. 137163. 
$\mathrm{Hu}, 1$, and Bentler, P. (1999) 'Cut-Off Criteria for fit indexes in covariance structure analysis: conventional criteria versus new alternatives', Structural Equation Modeling, Vol. 6, No. 1, pp. 1-55.

Huh, Y.U., Keller, F.R., Redman, T.C. and Watkins, A.R. (1990) 'Data quality', Information and Software Technology, Vol. 32, No. 8, pp.559-565.

Jiang, Z., and Benbasat, I. (2007a) 'Investigating the Influence of the Functional Mechanisms of Online Product Presentations', Information Systems Research, Vol. 18, No. 4, pp. 454-470

Jiang, Z., and Benbasat, I. (2007b) 'The Effects of Presentation Formats and Task Complexity on Online Consumers' Product Understanding', MIS Quarterly, Vol. 31 No. 3, pp. $475-500$

Jiang, Z., and. Benbasat. I. (2005) 'Virtual product experience: Effects of visual and functional control of products on perceived diagnosticity and flow in electronic shopping', Journal of Management Information Systems, Vol. 21 No. 3, pp. 111-148.

Kandemir, D., Yaprak, A. and Cavusgil, S.T. (2006) 'Alliance orientation: Conceptualization, measurement and impact on market performance', Journal of the Academy of Marketing Science, Vol. 34, No. 3, pp. 324-340.

Kempf, D.S., and Smith, R.E. (1998) 'Consumer processing of product trial and the influence of prior advertising: A structural modeling approach', Journal of Marketing Research, Vol. 35, No. 3, pp. 325-338.

Khakimdjanova, L., and Park, J. (2005) 'Online visual merchandising practice of apparel e-merchants', Journal of Retailing and Consumer Services, Vol. 12, pp. 307-318.

Kim, J. and Forsythe, S. (2009) 'Adoption of sensory enabling technology for online apparel shopping', European Journal of Marketing, Vol. 43, Nos. 9-10, pp.1101-1120

Kim, J., and Forsythe, S. (2007) 'Hedonic usage of product virtualization technologies in online apparel shopping', International Journal of Retail and Distribution Management', Vol. 35, pp. 502-514. 
Kim, J., Fiore, A., and Lee, H-H. (2007) 'Influence of Online Store Perception, Shopping Enjoyment, and Shopping Involvement on Consumer Patronage Behaviour Towards an Online Retailer', Journal of Retailing and Consumer Services, Vol. 14, pp. 95-107.

Kim, M., and Lennon, S. (2008) The Effects of Visual and Verbal Information on Attitudes and Purchase Intentions in Internet Shopping. Psychology \& Marketing, Vol. 25, No. 2, pp. 146-178

Klein, Lisa R. (2003) 'Creating Virtual Product Experiences: The Role of Telepresence', Journal of Interactive Marketing, Vol. 17, No. 1, pp. 41-55.

Kotler, P. (1973-74) 'Atmospherics as a marketing tool', Journal of Retailing, Vol. 49, No. 4, pp. 48-64.

Koufaris, M. (2002), “Applying the technology acceptance model and flow theory to online consumer behavior”, Information Systems Research, Vol. 13 No. 2, pp. 205-223.

Kwak, H., Fox, R. J., \&Zinkhan, G. M. (2002). What products can be successfullypromoted and sold via the internet? Journal of Advertising Research, 42(1), pp. 23-38.

Lee, K. Y. (2012). Consumer processing of virtual experience in e-commerce: A test of an integrated framework. Computers in Human Behavior, 28(6), 2134 2142 .

Li, D., Daugherty, T. and Biocca, F. (2003) 'The role of virtual experience in consumer learning',Journal of Consumer Psychology, Vol. 13, No. 4, pp.395407

Li, D., Daugherty, T., and Biocca, F. (2001) 'Characteristics of Virtual Experience in Electronic Commerce: a Protocol Analysis', Journal of Interactive Marketing, Vol. 15, No. 3, pp.13-30.

Li, D., Daugherty, T., and Biocca, F. (2002) 'Impact of 3-D Advertising on Product Knowledge, Brand Attitude and Purchase Intention: The Mediating Role of Presence', Journal of Advertising, Vol. 31, No. 3, pp. 43-57. 
Liao, T. H., andKeng, C. J. (2013). Online shopping delivery delay: Finding a psychological recovery strategy by online consumer experiences. Computers in Human Behavior, 29(4), 1849-1861.

Luan, J., Yao, Z., Zhao, F., and Liu, H. (2016). Search product and experience product online reviews: An eye-tracking study on consumers' review search behavior. Computers in Human Behavior, 65, 420-430.

McKinney, V., Yoon, K. and Zahedi, F. (2002) 'The measurement of web customer satisfaction: anexpectation and disconfirmation approach', Information Systems Research, Vol. 13, No. 3, pp.296-315.

Nelson, R.R., Todd, P.A. and Wixom, B.H. (2005) 'Antecedents of information and system quality: An empirical examination within the context of data warehousing', Journal of Management Information Systems, Vol. 21, No. 4, pp.199-236.

Novak, T. P., Hoffman, D. L., and Yung, Y. F. (2000) 'Measuring the customer experience in online environments: A structural modeling approach', Marketing Science, Vol. 19, pp. 22-44.

Nunnally, J. C. (1978). Psychometric theory (2nd ed.). New York: McGrawHill.

Oliver, R. L. (1996). Satisfaction: A behavioral perspective on the consumer. NewYork: McGraw-Hill

Overmars, S., andPoels, K. (2015). Online product experiences: The effect of simulating stroking gestures on product understanding and the critical role of user control. Computers in Human Behavior, 51, 272-284.

Pappas IO, Pateli AG, Giannakos MN, Chrissikopoulos V (2014).Moderating effects of online shopping experience on customer satisfaction and repurchase intentions.International Journal of Retail Distribution Management 42(3), pp. $187-204$

Park, J., Hill, W. T., and Bonds-Raacke, J. (2015).Exploring the relationship between cognitive effort exertion and regret in online vs. offline shopping.Computers in Human Behavior, 49, 444-450. 
Park, J., Stoel, L., and Lennon, S. (2008) 'Cognitive, affective and conative responses to visual simulation: The effects of rotation in online product presentation', Journal of Consumer Behaviour, Vol. 7, pp. 72-87.

Petty, R. E., \&Cacioppo, J. T. (1986).Communication and persuasion: Central and peripheral routes to attitude change. New York: Springer-Verlag.

Petty, R. E., Cacioppo, J. T., \& Schumann, D. (1983). Central and peripheralroutes to advertising effectiveness: The moderating role of involvement. Journal of Consumer Research, 10, 135-146.

Petty, R. E., Cacioppo, J. T., \& Schumann, D. (1983). Central and peripheralroutes to advertising effectiveness: The moderating role of involvement. Journal of Consumer Research, 10, 135-146.

Purwanegara, M., Apriningsih, A., and Andika, F. (2014).Snapshot on Indonesia regulations in Mobile Internet banking users' attitudes. Procedia-Social and Behavioral Sciences, 115, pp. 147-155.

Ratneshwar, S., \&Chaiken, S. (1991). Comprehension's role in persuasion: Thecase of its moderating effect on the persuasive impact of source cues. Journal of Consumer Research, 18, pp. 52-62.

Rodgers, W., Negash, S. Suk, K. (2005). The moderating effect of on-line experience on the antecedents and consequences of on-line satisfaction, Psychology and Marketing, 22(4),pp. 313-331.

Schlosser, A. E. (2003) 'Experiencing products in the virtual world: The role of goal and imagery in influencing attitudes versus purchase intentions', Journal of Consumer Research. Vol. 30, No. 2, pp. 184-198.

Serrano, B., Botella, C., Baños, R. M., andAlcañiz, M. (2013).Using virtual reality and mood-induction procedures to test products with consumers of ceramic tiles.Computers in Human Behavior, 29(3), 648-653.

Shih, Chuan-Fong (1998) 'Conceptualizing Consumer Experiences in Cyberspace', European Journal of Marketing, Vol. 32 No. (7/8), pp. 655-663.

Smith, P.W., Feinberg, R.A. and Burns, D.J. (1998) 'An examination of classical conditioningprinciples in an ecologically valid advertising context', Journal of Marketing Theory Practice,Vol. 6, No. 1, pp.63-72. 
Smith, R.E. (1993) 'Integrating information from advertising and trial: processes and effects onconsumer response to product information', Journal of Marketing Research, Vol. 30, No. 2,pp.204-219.

Steuer, J. (1992). Defining Virtual Reality: Dimensions of Determining Telepresence.Journal of Communication, VOL. 42, No. 4, pp. 73-93.

Streukens, S., Leroi-Werelds, S. (2016) Bootstrapping and PLS-SEM: A step-bystep guide to get more out of your bootstrap results, European Management Journal, Vol. 34, pp. 618-632

Suh, K-S., and Lee, Y. (2005) 'The Effects of Virtual Reality on Consumer Learning: An Empirical Investigation', MIS Quarterly, Vol. 29 No. 4, pp. 673697.

Sundar, S. S. (2007). Social psychology of interactivity in human-website interaction. In A. N. Joinson, K. Y. A. McKenna, T. Postmes, \& U.-D. Reips (Eds.), The Oxford handbook of Internet psychology (pp. 89-104). Oxford, UK: Oxford University Press.

Sundar, S. S., Kalyanaraman, S., \& Brown, J. (2003). Explicating Web siteinteractivity: Impression formation effects in political campaign sites. Communication Research, 30(1), 30-59.

Venkatesh, V., Morris, M.G., Davis, G.B. and Davis, F.D. (2003), "User acceptance of information technology: toward a unified view", MIS Quarterly, Vol. 27 No. 3, pp. 425-478.

Voss, K.E., Spangenberg, E.R. and Grohmann, B. (2003) 'Measuring the hedonic and utilitarian dimensions of consumer attitude', Journal of Marketing Research, Vol. 40, pp. 310-320.

Wilson, A. (2006). Marketing research: An integrated approach.(2 ${ }^{\text {nd }}$ Ed.). Harlow, England: Pearson Education Ltd.

Xu, Q., Sundar, S. S. (2014) 'Lights, Camera, Music, Interaction! Interactive Persuasion in E-commerce'Communication Research, Vol. 41(2) 282-308

Yoh, E., Damhorst, M. L., Sapp, S., andLaczniak, R. (2003). Consumer adoption of the Internet: The case of apparel shopping. Psychology \& Marketing, 20(12), 1095-1118. 
Yoon, V., Hostler, R.,Guo, Z. And Guimaraes, T. (2013) Assessing the moderating effect of consumer product knowledge and online shopping experience on using recommendation agents for customer loyalty. Decision Support Systems, 55, pp. 883-893

Zhilin, Y., Shaohan, C., Zheng, Z. and Nan, Z. (2005) 'Development and validation of aninstrument to measure user perceived service quality of information presenting web portals', Information \& Management, Vol. 42, No. 4, pp.575-589.

Zhou L, Dai L, Zhang D (2007) Online Shopping Acceptance Model—a critical survey of consumer factors in online shopping. Journal of Electronic Commerce Research, 8(1), pp. 41-62.

\section{Appendix A}

